\title{
La huella de la experiencia militar sobre el cuerpo uniformado A propósito de la serie Camuflajes (2003) del artista visual cubano Adonis Flores
}

\section{Dayma Crespo Zaporta}

Universidad Iberoamericana Ciudad de México

Traces of Military Experience on the Uniformed Body

On the "Camuflajes" Series (2003) by Visual Artist Adonis Flores

Recepción: 31 de enero de 2020

Aceptación: 1 de junio de 2020 


\section{Resumen}

Este artículo caracteriza y analiza la serie fotográfica Camuflajes (2003) del artista visual cubano Adonis Flores, para comprender cómo ésta devela su historia de vida. La experiencia como soldado en la guerra de Angola (con apenas 18 años de edad) funciona como detonante para la elaboración de una poética sobre los imaginarios sociales en el interior del universo militar, siendo "la homosexualidad como algo contagioso"1 uno de los temas más recurrentes. Es así que el cuerpo funge como un vehículo para la deconstrucción de dichos imaginarios y la sátira del discurso oficial. Para ello el fotógrafo se vale de determinadas estrategias estéticas y conceptuales que le permiten abrir un espacio de posibilidad a ciertas zonas de ocultamiento.

\section{Palabras claves}

Experiencia, soldado, imaginarios sociales, cuerpo, fotografía

\section{Abstract:}

This article characterizes and analyzes the photographic series Camuflajes (2003) by Cuban visual artist Adonis Flores, to understand how it unfolds his life story. His experience as a soldier in the Angolan war (at the age of 18 ) is the trigger for the elaboration of a poetics on the social imaginaries within the military universe, "homosexuality as something contagious" being one of the most recurrent topics. Thus, the body works as a vehicle for the deconstruction of these imaginaries and the satire of the official speech. To do this, the photographer uses certain aesthetic and conceptual strategies that allow him to open up a space of possibility for some areas of concealment.

\section{Key words:}

Experience, soldier, social conceptions, body, photography

1 Cfr. Judith Butler, Lenguaje, poder e identidad. 
La línea que separa lo nombrable de lo innombrable establece los límites actuales de la sociedad

Judith Butler

\section{La fuerza de la historia de vida}

LA CONFIGURACIÓN DE UNA POÉTICA ARTISTICA RESULTA UNA TAREA COMPLEJA, SOBRE todo frente a la vorágine siempre creciente del arte contemporáneo. Sin embargo, algunos artistas han hallado la manera de configurar una visualidad y un discurso singulares, emanados de experiencias personales muy profundas que los llevan a la reflexión, y más tarde, a proponernos cuestionamientos fecundos sobre males que nos hostigan a diario. Tal es el caso del arquitecto cubano Adonis Mariano Flores Betancourt (Sancti Spíritus, Cuba, 1971), ${ }^{3}$ quien con su serie Camuflajes (2003) entró en el mundo de la fotografía y el performance, en virtud de dialogar sobre "lo militar" y las dinámicas que esto determina. Comenzó esta serie de performances y fotografías a partir de dos sucesos puntuales: el primero, su servicio militar como soldado en Angola ${ }^{4}$ con tan sólo 18 años y, más tarde, la caída de las Torres Gemelas en Estados Unidos, ${ }^{5}$ hecho que lo llevó a una reflexión retrospectiva sobre los intríngulis del universo militar.

La guerra de Angola representa en el imaginario del pueblo cubano un duelo infinito e indescriptible, con más de dos mil caídos en combate en suelo africano, sin contar aquellos que aun regresando vivos dejaron la

2 Butler, Lenguaje, poder e identidad, 200.

3 Graduado de Arquitectura en la Universidad de Las Villas, en 1997.

4 Durante la guerra civil de descolonización de Angola (la más rica de las colonias portuguesas), el gobierno cubano, con Fidel Castro a la cabeza, brindó ayuda solidaria a este país africano mediante un despliegue militar que duraría de 1975 a 1991. Bajo el nombre de Operación Carlota, numerosas milicias cubanas fueron a ayudar al país del cono sur africano, durante el gobierno de izquierda de Agostinho Neto (presidente del Movimiento Popular de Liberación de Angola, MPLA), ante el acecho de la apartheidista y de derecha Unión Nacional para la Independencia Total de Angola (UNITA) y del Frente Nacional de Liberación de Angola (FNLA), la cual tenía el respaldo de Sudáfrica, Zaire y Estados Unidos. La ayuda cubana consistió en el envío de instructores, la preparación de cuadros y asistencia en términos materiales.

5 Dayma Crespo, Entrevista a Adonis Flores. 
lucidez en el proceso traumático de la guerra. Pero a la vez, y paradójicamente, representa el orgullo de haber cumplido el deber y de morir en ese empeño. Se considera que nunca antes un pueblo latinoamericano había asumido una proeza militar de tal envergadura. La Unión Soviética colaboró en gran medida con el armamento, pero los cubanos pusieron el capital humano, en el argot popular, "la carne de cañón". Estamos hablando de numerosas familias víctimas de la pérdida de un ser querido, de la imposibilidad de velar a muchos, pero de alguna forma entonces todos cedieron frente a esa iniciativa solidaria porque se sentía como lo correcto a hacer en ese momento puntual del proceso revolucionario.

Ante el parteaguas político internacional que supuso el atentado al World Trade Center el 11 de septiembre de 2001, Adonis Flores se cuestionó la posibilidad de una Tercera Guerra Mundial, las posturas gubernamentales frente a esto, el poder ilimitado del ejército de un país, y los millones de vidas y cuerpos altamente vulnerables involucrados en el proceso. Es así que retoma, desde la distancia temporal, muchas de sus vivencias como soldado, al percatarse de la universalidad del tema militar y de la condición liminal de aquellos que lo viven en carne propia. Viaja en el tiempo a su temprana juventud y a los desmanes vivenciados por él, a los traumas psicológicos que lleva consigo, en aras de invitar al cuestionamiento respecto a todo aquello que pesa sobre el cuerpo de un soldado. Abre el diálogo a una profesión que tenemos naturalizada como la de profesor o deportista; llama la atención sobre la responsabilidad, el desaliento, y los estereotipos que la acompañan, donde la voz de mando resulta plenipotenciaria. Pero, ¿qué queda bajo esas imágenes regias de los uniformados, bajo la disciplina y el orden? Ésos son los intersticios que la serie Camuflajes nos convida a dilucidar.

Como parte de la división cultural entre las características y comportamientos de lo masculino y lo femenino, se construye también la imagen o el imaginario del militar; por lo general hombre, fornido, valiente, invencible, protector de todos, resistente a los mayores desmanes y ultraheterosexual. No caben entonces en este grupo aquellos que lloran, no so- 
portan una tortura, se trastornan mentalmente frente a los horrores que viven en la guerra, gustan sexualmente de otro hombre o del acto de travestirse. Y es que la propia vestimenta, las normas de cómo llevar el cabello, la austeridad, el seguimiento ciego de órdenes y hasta las posturas de mando construyen una idea del militar que lo encierra, limita y amenaza con la exclusión, en caso de transgredir estas reglas de alguna manera.

Flores nos conduce entonces a repensar al ejército, como institución poderosa, la cual orienta sus esfuerzos a la despersonalización, a la ruptura de la individualidad, en función de homogeneizar a la masa de soldados. De ahí que la conversión en soldado se pueda entender como un ritual de paso ${ }^{6}$ mediante el cual el individuo es separado de su entramado social, puesto al margen y luego agregado nuevamente, tras un renacer simbólico. Lo cierto es que no vuelven a ser los mismos, pues la mente y el cuerpo se transforman de manera notable. Como parte de ese tránsito se busca disciplinar, volver obediente al sujeto, convencerlo de que no hay nada más allá de una orden, una misión, y de que al cumplir ciegamente esas encomiendas va a ser un héroe. Es entonces que se desdibujan las prioridades en la vida, los anhelos, los sueños, y se acaba naturalizando lo bélico como la cotidianeidad, la muerte como una pesadilla al acecho y la pérdida de seres queridos como parte del día a día. No es que todo ese entrenamiento los haga más fuertes, más bien induce a la ruptura de algo en términos sentimentales, donde el horror se vuelve su experiencia estética más cercana. En el militar se funden dos sujetos: quien desempeña el rol social de defensor de la nación, de poseedor de una fuerza legítima —una suerte de "licencia para matar"- para ejercer violencia en contextos puntuales, y otro que es una persona común y corriente con individualidades marcadas por el existencialismo, el miedo y hasta la desesperanza. Su mente parece estar lavada por la autoridad del sistema, pero en momentos de total presión pudiera reaccionar de forma traumática ante la violencia psicológica ejercida, lo cual originaría un punto de fuga en el dominio que

6 Cfr. Arnold Van Gennep, Los ritos de paso. 
se tiene sobre su cuerpo. ${ }^{7}$ El soldado representa entonces ese punto de fundición, donde la institución militar se visibiliza mediante el sujeto que se jugará la vida por su causa (la de la institución militar). ${ }^{8}$

En esta rutina, el creador se percató de la ambivalencia que inunda ese universo, donde el camuflaje es en efecto una práctica habitual, pues se vuelve necesario ocultar desde la preferencia sexual hasta los miedos y demostraciones de afecto, donde pretender es lo más importante, en aras de mantener en alto determinados "paradigmas". No sólo hay camuflaje en el uniforme, sino en todo lo demás: desde los discursos exhortadores hasta la esencia misma de quien se debe adentrar en ese entorno hostil. De ahí que el artista decidiera tomar su antiguo y polvoriento uniforme militar y convertirlo, junto a su cuerpo, en la principal estrategia visual y discursiva de su poética. Se trata entonces de un proceder artístico que pone en tensión todo lo "inmaculado" y viril propio de la parafernalia militar, así como la idea de heroísmo que implica el paso adelante ante la guerra; frente a la "femineidad" intrínseca a cada uno de sus miembros, ya sea a través de la dulzura de la oratoria, la sutileza al danzar, o cuestionando la ambigüedad del lenguaje y la bufonería de todo ese montaje.

Es una poética que desautomatiza nuestra manera de concebir el tipo social del militar, que deconstruye los conceptos inmaculados que lo rodean y llega a desacralizar el rol que juegan en el entramado social. Sin embargo, no es un acto crítico irreverente y sin fundamento, más bien una puerta abierta para repensar esta imagen uniformada, desmontando los estereotipos que la circundan, en aras de romper las restricciones que constantemente encierran a sus miembros en una burbuja del "deber ser", en un camuflaje perenne, confinándolos al "pretender" como un hábito de existencia. Se trata entonces de una reversión de la práctica habitual, en la que

\footnotetext{
7 Véase Hamlet Fernández, "Camuflajes, metáforas y metonimias", 8-22.

8 Las ideas anteriores se sustentan en la noción de militar en contextos determinados, entre ellos Cuba, pues en otras circunstancias es una figura entendida a partir del ejercicio de la violencia, como seres tiránicos y despiadados que arremeten contra la población civil y acaban librándose de la ley por su condición de ley per se.
} 
el "personaje soldado" acaba suprimiendo al ser humano que lo porta; en pos de llevar al sujeto a su límite de humanidad hasta que subyugue al "rol del soldado".

\begin{abstract}
Su manera de abordar una temática tan espinosa y difícil de manejar sin caer en el panfleto ideológico, lograba un juego metafórico capaz de producir disímiles corrimientos de sentido entre el signo-soldado (sujeto-rol) y su referente normativo (las funciones que asociamos al universo de lo militar). ${ }^{9}$
\end{abstract}

Es así que la serie Camuflajes consta de alrededor de 30 piezas hasta el momento, de las cuales cinco son acciones performáticas y el resto son fotografías en impresión digital con dimensiones variables. El artista comenzó a conformarla desde 2002, pero no fue sino hasta 2003, con Visionario, que sintió que la idea tenía la madurez necesaria como para mostrarla. La primera vez que exhibió estas obras en conjunto fue en Galería Habana, un espacio galerístico privilegiado dentro del entramado capitalino cubano, bajo el título de Carne de cañón, en los meses de julio y agosto del 2007. El concepto de la misma era, en palabras del especialista Hamlet Fernández, "provocar una subversión radical del rol al interior de la estructura del Orden Militar". ${ }^{10}$ No obstante, Camuflajes es una serie abierta, sin fecha de término declarada, pues se trata de una temática que representa uno de los ejes principales de la poética de Adonis Flores; de ahí que permita mantenerse en constante crecimiento. En ella encontramos un cauce vital para acercarnos: los títulos, que nos indican qué debemos mirar en las obras, como guías; qué intención-autor está mediando y, en este sentido, nos condiciona un tanto la recepción. Sin embargo, en muchas obras resulta indispensable una intervención a partir del título, en aras de lograr una aproximación a la idea original que le dio vida en la mente del artista.

9 Fernández, "Camuflajes, metáforas y metonimias", 11.

10 Fernández, "Camuflajes, metáforas y metonimias", 11. 


\section{El cuerpo como vehículo}

El cuerpo ${ }^{11}$ en la obra fotográfica de Adonis Flores es un medio o vehículo para conducir al receptor a espacios de análisis reflexivos en torno a problemáticas emanadas del universo militar, pero que hallan cabida en muchos otros escenarios. Es una estrategia visual y discursiva, capaz de ofrecer una multidimensionalidad desde la cual acercarnos a su propuesta: ya sea desde los estudios de género, desde la sociología como un fenómeno generador de imaginarios sociales, ${ }^{12}$ desde la antropología con el estudio de las emociones y de la violencia física y simbólica, entre otros prismas para mirar. El cuerpo constituye un caleidoscopio, de ahí que siempre que lo miremos encontremos numerosas lecturas, pues su principal característica es la polisemia.

11 El cuerpo humano ha sido abordado por numerosas ciencias, desde las naturales con un perfil biológico, hasta las sociales, para entenderlo como un fenómeno sociocultural con características puntuales. La historia, la antropología (cultural fundamentalmente) y la sociología son disciplinas que han contribuido al entendimiento del cuerpo en el arte como un ente simbólico cargado de polisemias.

Para ello partiremos de la premisa de que estas tres disciplinas no andaban por senderos del todo exclusivos y solitarios, sino que el préstamo, la cita y el afán de continuar los hallazgos clarificadores del fenómeno, van a ser sumamente recurrentes, dando lugar a una suerte de transdisciplinariedad (quizás inconsciente) dentro de esta problemática, la cual se manifiesta tanto en el cruce de teorías como en la formación profesional de sus principales exponentes. Gracias a estos pensadores y teorías podemos referirnos hoy al cuerpo como un enfoque dentro de los estudios de arte. Para mayor desarrollo del tema, véase Genevieve Galán, "Aproximaciones a la historia del cuerpo como objeto de estudio de la disciplina histórica", 167-204.

12 Alexander Cano explica que lo que hoy entendemos como imaginario no es más que la evolución o ampliación del término "mentalidades", ante la ambigüedad que este último planteaba para la expresión de "las actitudes mentales, las visiones colectivas de las cosas, los universos culturales, los sentimientos y creencias de una sociedad con unas coordenadas espacio-temporales determinadas". Ante esta situación, la categoría "mentalidades" se mostraba débil y vaga como definición teórica, aunque al escuchar cómo la concebían vemos sus proximidades extremas con la noción de imaginario. El historiador Gilbert Durand ofrece una conceptualización para las mentalidades como: "el conjunto de imágenes y relaciones de imágenes que constituye el capital del pensamiento del homo sapiens [...], el zócalo común que modela el pensamiento de cada grupo de hombres que vive en sociedad". Véase Alexander Cano, "De la historia de las mentalidades a la historia de los imaginarios sociales", 138. 
No resulta fortuito el hecho de que Adonis Flores sea su propio modelo. El hacer referencia a su imagen declara la intencionalidad de tomar su experiencia en la guerra como punto de partida para la elaboración de un discurso sobre el andamiaje militar. Es su cuerpo (y no otro) aquel que puede describir las microhistorias emanadas de esa vivencia. No es sólo su relato, sino el de todos aquellos implicados en esa acción, son reflexiones que desde la distancia crítica le pueden permitir resignificar ese pasado. En este sentido, el cuerpo del artista es un dispositivo para la redacción de una historia diferente a la oficial, distante del discurso elucubrado y ortodoxo de la militancia heroica de un país. De repente, su cuerpo es un símbolo que representa el cuerpo de todos los militares, de aquellos que en algún momento pasarán ese ritual, e incluso de los que desde la distancia nos acercamos a su obra. Su intención es situar al espectador en esa posición, incomodarlo, perturbar la imagen impoluta y heteronormada del militar que tiene tatuada en la mente, interpelarlo y llevarlo a la duda, a la generación de un espacio de posibilidad para esos intersticios donde nace "la diferencia".

Igualmente, tiene un valor añadido que su cuerpo aparezca ataviado con el uniforme militar, una vestimenta que es universal, con claros objetivos de confundirse con las zonas boscosas, ya sea para el ataque sorpresivo o para ocultarse del enemigo. Además, se trata del uniforme que usó durante el año que permaneció en Angola, de 1989 a 1990, lo cual le otorga otra carga simbólica a la imagen, un gesto que acaba ratificando el enunciar estas problemáticas desde un lugar puntual, con una toma de posición frente a la maquinaria imparable que es el ejército. Por ello resulta lógico que esta serie fotográfica se encuentre acompañada por variados performances, los cuales dotan de movimiento las subversiones que propone para repensar este universo.

El cuerpo del artista saca a la luz la idea del testimonio, como si quisiera contar su propia historia o la de sus compañeros a través de tópicos que abre al diálogo. Dentro de esa masa compacta de realidad y ficción que nos presenta, su cuerpo es la dosis de veracidad, pues ciertamente estuvo en 
la guerra, carga con la experiencia y desde ese sitio parte su narrativa. El cuerpo de Flores es entonces vivencia e identidad, pues a partir de esos relatos se construye un ser que ya nunca será el mismo; esa experiencia lo atraviesa, lo forma, lo fragmenta y determina inevitablemente. Camuflajes habla de un Adonis Flores que puede ser cualquiera, pero que existe y se expresa desde el acontecer bélico en el cual se vio involucrado.

Es así que el camuflaje deviene una actitud ante la vida, una praxis vital para el creador, quien halla en las sutilezas del lenguaje visual un nicho donde generar imágenes críticas. Su proceder artístico está marcado por el gesto, irreverente y transgresor, que juega con la dicotomía entre aquello que vemos y lo que se oculta, entre el exterior y el interior. La gestualidad del soldado muestra la heteronormatividad del sistema, la robustez de una ortodoxia que manipula a los sujetos; sin embargo, Flores subvierte esto al hacer explícitas muchas de esas emociones que se transfiguran tras las apariencias, al deconstruir aquello que se encuentra normalizado.

\section{Paranoia homofóbica vs. homosexualidad}

La filósofa estadounidense Judith Butler trabaja en su libro Lenguaje, poder e identidad (1997) la paranoia y homosexualidad en el ejército estadounidense, a partir de la relación entre el lenguaje y su capacidad de "contagio". Tras valerme de esta perspectiva teórica para ver la forma psicoanalítica en que operan ciertos fenómenos aquí en juego, a partir del juramento militar analizaré la manera de entenderse en el contexto cubano la noción de "hombre nuevo", palabras de Fidel Castro Ruz, y libros que abordan el fenómeno homosexual tanto con afirmaciones homofóbicas como desde una perspectiva crítica.

Judith Butler apunta, en este sentido, cómo la homosexualidad fue vetada en el ejército de Estados Unidos, pero sólo a nivel de autodefinición. Es decir, en tanto el soldado no se autodeclare homosexual, la institución militar no lo 
entiende como tal y por ende, no lo expulsa. Ahora bien, ¿por qué la marginación de la homosexualidad del universo militar? Esto responde al registro del lenguaje perlocucionario, donde lo verbalizado toma a posteriori forma performativa, o sea, el afirmarse homosexual atañe una consecuencia en el campo del contacto físico. Este reconocimiento como homosexual implica la práctica de "actos" homosexuales que, sean repetidos o no, son sentenciados como "conducta", elemento que lo imprime en una temporalidad infinita. ${ }^{13}$

Asimismo, se introduce la paradoja de cómo las normas y regulaciones, lejos de lograr en efecto la proscripción de ciertas prácticas, las colocan en boga en el contexto. De ahí que ante estas normativas, el debate sobre la homosexualidad haya acabado por ganar un espacio en el discurso público. En este sentido, la prohibición y la expansión de un término como homosexual junto a un ejemplo de sujeto al que hace referencia no son directamente proporcionales, ya que no se puede proscribir algo sin referirse lingüísticamente a ese algo, momento en el cual nos percatamos de una disrupción entre el discurso de la homosexualidad y su referente (la homosexualidad en sí). Tratar de definir de forma tácita significaría limitar este concepto, pues aún no encuentra un referente que le ajuste de manera exacta, algo que amplía su vida lingüística en el tiempo, pero a la vez genera confusión e impide la construcción de una política eficaz para esta comunidad. ${ }^{14}$ Las prácticas sexuales contemporáneas desbordan el espectro de la homosexualidad, por eso este término cada vez se vuelve más incapaz de asir la gran complejidad de género que nos asiste en la actualidad.

En palabras de Butler: "La regulación del término no es, pues, un simple acto de censura o silencio: por el contrario, la regulación redobla el término que quiere restringir, y sólo puede efectuar esa restricción mediante ese paradójico redoblamiento". ${ }^{15}$ Es aquí donde entra la obra de Adonis Flores, pues al partir de lo que es políticamente correcto define los límites de su

13 Cfr. Butler, Lenguaje, poder e identidad.

14 Cfr. Butler, Lenguaje, poder e identidad.

15 Butler, Lenguaje, poder e identidad, 177. 
poética, volcada a ese segundo instante donde se redobla lo fantasmáti$c o,{ }^{16}$ lo que debería permanecer oculto pero nunca se va, pues coexiste y se contrapone a la normativa.

Por otro lado, la denominación, categorización y demás actos de señalamiento siempre han de partir de una segunda instancia, el Ejército o el Estado en este caso, de alguien que no se autodefina como tal y por ello pueda ejercer la neutralidad o la justicia. Es un término que nace desde una posición hegemónica para designar a otros, generando un espacio de otredad como consecuencia de una clara relación de poder. Lo anterior tiene su razón de ser en la prohibición de pertenecer al ejército en caso de autodefinirse como tal, pues la negación propia de esa identidad es la única manera de pertenecer.

Ese ejercicio de autorreconocimiento "amenaza" la moral militar en cuanto que conduce de manera inmediata al entendimiento de una conducta homosexual contagiosa, que lejos de recaer sobre el propio sujeto, se piensa que realiza proyecciones de deseo solícitas sobre aquellos que lo rodean. La idea del contagio o propagación de un sentir homosexual se corresponde directamente con el impacto del sida en el mundo y los estigmas con que cargó la comunidad gay en ese momento y que arrastra como una cicatriz hasta la actualidad. ${ }^{17}$

Una vez que autodenominarse "homosexual" constituye una afirmación de esa condición no aceptada en el Ejército, los homófobos devienen la representación de la sensatez en este espacio, y a su vez esa conducta homofóbica marca la aparición de la paranoia. Los homófobos acaban siendo paranoicos pues pretenden alejar al máximo esa amenaza de contagio homosexual, reprimen cualquier comportamiento que pudiera entenderse

16 Según la Real Academia Española, fantasmático es un adjetivo derivado de fantasma: dícese de una representación mental imaginaria que puede estar provocada por el deseo o el temor. Y éste es un punto de partida interesante, pues evidencia la idea de que repulsamos aquello desconocido, que por diferente nos provoca miedo y, por ello, decidimos discriminarlo.

${ }^{17}$ Cfr. Butler, Lenguaje, poder e identidad. 
como conducta gay ante el peligro de una "propensión" a ese abismo. Butler lo resume de la siguiente forma: "el ejército produce una interpretación paranoica de la declaración homosexual como una acción contagiosa y ofensiva, como si se realizara o constituyera aquello a lo que se refieren tales enunciados". 18

Aun cuando el análisis de Judith Butler nos conduce a la psiquis del sujeto homofóbico que margina, es igualmente una manera de pensar esa estructura de poder en otros sentidos, en cuanto a jerarquías y normativas que finalmente son dictadas desde el Ejército o el Estado. Asimismo, debemos tener en cuenta que es un texto de 1997, pues ciertas cuestiones ahí planteadas no poseen del todo un eco en la contemporaneidad. Tal es el caso de la idea del contagio de la homosexualidad a través del lenguaje, es decir, al ser interlocutor de alguien. Hoy día la ciencia ha demostrado que el sida no es un padecimiento privativo de las personas homosexuales y que el contagio demanda necesariamente el contacto sexual con el infectado. Sin embargo, un elemento de gran importancia sería la suerte de sincronía en términos homofóbicos entre Cuba y Estados Unidos; este último país, en el momento en que se escribió este texto tenía una ley que prohibía la autodenominación como gay, cuestión que en Cuba fue manifestada a través de textos con toques homofóbicos, lineamientos en el Congreso Nacional de Educación y Cultura de 1971, e incluso en discursos del Comandante en Jefe, expresiones que quedaron bajo el velo del "deber ser" de un revolucionario en una sociedad socialista como la cubana.

Por otro lado, corresponde matizar la alta complejidad del contexto posrevolucionario, heredero de una tradición homofóbica y patriarcal que antecede al proceso revolucionario por siglos; así como la noción de modernidad rupturista que lo acompañó, entorno en el que toda expresión de "diferencia" podía ser confundida con debilidad y peligro latente de boicotear la Revolución. No se trata de poner en una balanza cuán correctas fueron las

18 Butler, Lenguaje, poder e identidad, 181. 
acciones asumidas por el gobierno en este periodo, sino de reflexionar desde la distancia histórica - al igual que lo hace Adonis Flores— las contradicciones de un proyecto nuevo que implicaba aciertos y desaciertos, en el cual la homofobia fue sin duda una de sus páginas menos felices.

La idea de partir de Butler, para luego entender procesos similares en Cuba, responde a la especificidad de su texto, al situarlo en el ejército estadounidense y no en un contexto más indeterminado; asimismo, al bagaje teórico que le brinda a este estudio. Sin embargo, la edificación de la Revolución cubana contó con manifestaciones homofóbicas que estuvieron siempre mediadas por lo patológico y lo político. La identidad homosexual fue entendida como desviación sexual y, a su vez, como diversionismo ideológico.

Si bien el texto de la filósofa estadounidense se publicó en 1997, dos años más tarde, en 1999, salió a la luz en Cuba el libro Homosexualidad, homosexualismo y ética humanista, de la autoría de Felipe de J. Pérez Cruz y publicado por la Editorial Ciencias Sociales. ${ }^{19}$ Se trata de un texto altamente homofóbico y que evidencia una pobreza científica a la hora de referirse a la homosexualidad. En este sentido, desconoce fenómenos como las Unidades Militares de Ayuda a la Producción (UMAP), dedicadas desde 1965 a retirar del entramado social revolucionario los elementos considerados "antisociales", tales como los homosexuales y los religiosos. Esta estrategia reformadora respondía a la idea de que la homosexualidad y otros "lastres entorpecedores" eran males heredados de la época republicana y por ello requerían un proceso de reeducación mediante el trabajo político, ideológico y productivo. Es así que les eran dadas labores como la zafra, cuyas estadísticas recibían gran despliegue mediático, en aras de probar la eficacia de ese método de higienización social. ${ }^{20}$ El libro de Pérez Cruz intenta, mediante argumentos no sin cierto

19 La editorial Ciencias Sociales, desde su fundación en 1967, ha recibido el apoyo de la Revolución por encaminar su labor a la inmortalización editorial de momentos épicos culturales y políticos del país. Goza de prestigio y cubre tópicos económicos, políticos, históricos, filosóficos, jurídicos, etnológicos, lingüísticos, psicológicos, sociales, entre otros.

20 Abel Sierra, Del otro lado del espejo. La sexualidad en la construcción de la nación cubana, 197. 
sinsentido, justificar en alguna medida la política de saneamiento homosexual que tuvo lugar en los decenios del sesenta y el setenta. ${ }^{21}$ Ya para 1975 estaba comenzando la guerra de Angola; de ahí que podamos conectar directamente la idea de homosexualidad que se manejaba en Cuba cuando Adonis Flores ingresó al ejército. No obstante, resulta curioso que este tipo de obras las realice desde la distancia histórica del nuevo siglo, pues en efecto es su recurso para retomar el tema con mayor claridad, desde el razonamiento de los años, con una mayor capacidad analítica que le permita situarse de un lado del debate, al estar de acuerdo o no con este comportamiento. Es entonces cuando reparamos en la fuerza política que entraña el arte y cómo éste permite un cuestionamiento de la historia de sociedades puntuales.

El autor de Homosexualidad, homosexualismo y ética humanista igualmente recurre a la ideología de los sistemas políticos al argüir que la homosexualidad era un fenómeno sintomático del capitalismo posmoderno, criterio que da cuenta de su desconocimiento respecto a la lucha de los movimientos homosexuales a nivel internacional y de las posturas altamente radicales de gobiernos, como el estadounidense, al respecto. ${ }^{22}$

Asimismo, fue recurrente partir de la apariencia para definir la conducta homosexual y saber cómo identificarla para combatirla. De ahí que fuera asociada con el hippismo de fines de los sesenta en Estados Unidos y con consiguientes elementos como las sandalias, el cabello largo, los jeans ("pitusas"), el rock and roll, el grupo musical británico The Beatles, etcétera. Todo ello fue ubicado en "una otredad impropia a la nación y considerado por algunos funcionarios de la ortodoxia revolucionaria de entonces, como símbolos o expresiones de diversionismo ideológico". ${ }^{23}$ No resulta fortuito entonces que el Comandante en Jefe, Fidel Castro, en la clausura del acto para conmemorar el VI aniversario del Asalto al Palacio Presidencial, celebrado en la Escalinata de la Universidad de La Habana el 13 de marzo de 1963,

21 Sierra, Del otro lado del espejo, 200.

22 Sierra, Del otro lado del espejo, 201.

23 Sierra, Del otro lado del espejo, 201. 
ante una pregunta del público por "ilos flojos de pierna, Fidel!, ¡los homosexuales!", ${ }^{24}$ respondiera:

[...] Muchos de esos pepillos vagos, hijos de burgueses, andan por ahí con unos pantaloncitos demasiado estrechos (RISAS); algunos de ellos con una guitarrita en actitudes "elvispreslianas", y que han llevado su libertinaje a extremos de querer ir a algunos sitios de concurrencia pública a organizar sus shows feminoides por la libre.

Que no confundan la serenidad de la Revolución y la ecuanimidad de la Revolución con debilidades de la Revolución. Porque nuestra sociedad no puede darles cabida a esas degeneraciones (APLAUSOS). La sociedad socialista no puede permitir ese tipo de degeneraciones.

Hay unas cuantas teorías, yo no soy científico, no soy técnico en esa materia (RISAS), pero sí observé siempre una cosa: que el campo no daba ese subproducto. [...]

Estoy seguro de que independientemente de cualquier teoría y de las investigaciones de la medicina, entiendo que hay mucho de ambiente, mucho de ambiente y mucho de reblandecimiento de ese problema. Pero todos son parientes: el lumpencito, el vago, el elvispresliano, el "pitusa" (RISAS). ${ }^{25}$

La actitud gubernamental cubana posrevolucionaria de las primeras décadas queda manifiesta en estas palabras, desde la ovación del público con cierta sed de sangre sobre "los flojos de pierna", a los que toda esa política de no tolerar "degeneraciones" le parecía muy simpática, hasta la asociación con la vagancia, cosa que el campo de "hombres rudos" no fomentaba. Hay muchas lecturas que hacer entrelíneas de estas palabras, dígase la construcción de un criterio a partir de la manera de vestir de estas personas, su gusto por la música al portar y tocar guitarras, y la presenta-

24 Fidel Castro, Discurso pronunciado por el Comandante en Jefe Fidel Castro Ruz en la clausura del Acto para conmemorar el VI aniversario del Asalto al Palacio Presidencial, 11. 25 Castro, Discurso pronunciado por el Comandante en Jefe Fidel Castro Ruz en la clausura del Acto para conmemorar el VI aniversario del Asalto al Palacio Presidencial, 11-12. 
ción en público para hacer uso de esos comportamientos abominables no reconocidos por la Revolución. El asumir la inclusión de este sector de la población era considerado una debilidad del sistema, pues las acuñaron de "degeneraciones" sin cabida en la sociedad socialista. ¿Qué podía venir tras eso? Sin duda alguna las UMAP, para enderezar aquello que como un árbol estaba torcido, pero que la Revolución confiaba en que se podía enderezar su tronco. Al final de la frase citada plantea la idea de la homosexualidad como una patología a estudiar por la medicina, y la sentencia de que vagancia, parasitismo, música foránea y hippismo son sinónimos todos, siendo finalmente el homosexual una conjunción de todas esas lacras sociales, donde venía implícita la "gusanera". ${ }^{26}$ "Entonces, consideramos que nuestra agricultura necesita brazos (exclamaciones de: “¡Sí!”); y que esa gusanera lumpeniana, y la otra gusanera, no confundan La Habana con Miami”. ${ }^{27}$

Por su parte, en el Congreso Nacional de Educación y Cultura de 1971 se presenció una declaración abiertamente antihomosexual en el diseño de la política nacional. Como alegato a esa postura hubo razones como su carácter de "desviación" y "patología social". ${ }^{28}$ Luego manifiestan la implementación de "medidas preventivas y educativas" para lograr el "saneamiento y control de los focos homosexuales". ${ }^{29}$ Ante tales medidas, no asombran luego los testimonios recurrentes entre la población cubana sobre los expulsados de la universidad, por argüirse que llevaban a cabo dichas prácticas. Igualmente, plantearon la necesidad de evitar que estos sujetos homosexuales sean los responsables en la esfera cultural de representar al país en el extranjero, por ser considerados personas "cuya moral no responda al prestigio de nuestra Revolución". ${ }^{30}$ Lo curioso del asunto es

\footnotetext{
26 En Cuba se le llama gusano a los elementos contrarrevolucionarios que desde el inicio de la Revolución han tratado de boicotear el sistema en conjunción con Estados Unidos.

27 Castro, Discurso pronunciado por el Comandante en Jefe Fidel Castro Ruz en la clausura del Acto para conmemorar el VI aniversario del Asalto al Palacio Presidencial, 12.

28 Congreso Nacional de Educación y Cultura, Memorias, 203.

29 Congreso Nacional de Educación y Cultura, Memorias, 203.

30 Congreso Nacional de Educación y Cultura, Memorias, 203.
} 
que en la confección de estos postulados estuvo a cargo un panel de especialistas y luego fueron publicados en un folleto médico, por considerarse un asunto de índole patológica. ${ }^{31} \mathrm{~A}$ decir del historiador cubano Abel Sierra Madero:

podría hablarse incluso de un continuum histórico discursivo que inscribe la homosexualidad en el terreno de lo patológico con "graves repercusiones sociales", cuando deja de ser un sentimiento íntimo o privado y se manifiesta de manera individual o colectivamente en el plano social; es decir, cuando "se hace ostentación de tal condición". ${ }^{32}$

Esta cita nos conecta directamente con los planteamientos de Butler respecto a lo contagiosa que puede llegar a ser la homosexualidad. El tema no es serlo, sino el osar reconocerlo en medio de un entorno político dado; de ahí que estas ideas no hicieran más que guiar a la frustración como seres humanos a aquellos que decidieran declarar su preferencia sexual.

Al incorporarse al Servicio Militar ${ }^{33}$ Adonis Flores juró ante las Fuerzas Armadas Revolucionarias (FAR) un conjunto de valores y acciones que definirían de ahí en lo adelante los estándares sobre los cuales sería evaluado

31 Sierra, Del otro lado del espejo, 198-199. El autor argumenta cómo en 1972 se realizó un "Ciclo de conferencias sobre educación sexual", a cargo de la Dirección Nacional de Educación para la Salud, donde se dedicó un momento a las "variantes y desviaciones sexuales", en el que se ponía la homosexualidad a la altura del incesto, el voyeurismo y la pedofilia, entre otros ejemplos.

32 Sierra, Del otro lado del espejo, 199.

33 Para la incorporación de las jóvenes generaciones a la defensa y el completamiento de las FAR con unas reservas preparadas patriótica y militarmente, se promulga el 26 de noviembre de 1963 la Ley No.1129. La misma estableció el Servicio Militar Obligatorio (SMO). También se crearon los comités militares, las comisiones de reclutamiento y las oficinas de inscripción en el smo. El primer llamado fue en 1964, pues la defensa de la patria era tarea de todos y no sólo de unos pocos, parafraseando el discurso del Comandante en Jefe Fidel Castro el 26 de julio de 1963. Luego, en 1973, se pasa a la Ley No. 1255 del Servicio Militar General. Más tarde, en 1994, se pone en vigor la Ley No. 75 "De la Defensa Nacional", bajo la concepción de "Guerra de Todo el Pueblo". Finalmente, el 15 de octubre de 2001, se aprobó el Decreto Ley No. 224 del Servicio Militar (Activo) y de la reserva, donde queda claro su carácter obligatorio a los 18 años de edad para los varones, según la Ley No. 75. 
al interior de lo militar. Este discurso manifiesta una construcción simbólica del ciudadano revolucionario y socialista, que mediante preceptos "políticos" acaba moldeando un tipo de sujeto a construir por la Revolución. Se debe tener en cuenta, además, que la puesta en marcha del concepto de "hombre nuevo", retomado en el contexto cubano por Ernesto Che Guevara - que era una suerte de sinónimo de revolucionario- se convirtió en la promulgación de un ideal de hombre ateo y heterosexual para toda la sociedad, llegando a normar desde quiénes podían entrar a la universidad hasta los que eran aptos para integrar las filas de la Unión de Jóvenes Comunistas (UJC) o del Partido Comunista de Cuba (PCC). Obviamente el Ejército no sería la excepción de esta promulgación; de ahí las impresiones que Flores vuelca en sus obras respecto a ese orden y regulación.

El profesor de la Universidad Central de Venezuela, Fidel Canelón, lo sintetiza de la siguiente manera:

Una Revolución sólo es auténtica cuando es capaz de crear un "Hombre Nuevo" y este, para Guevara vendrá a ser el hombre en el siglo XXI, un completo revolucionario que debe trabajar todas las horas de su vida; debe sentir la revolución por la cual esas horas de trabajo no serán ningún sacrificio, ya que está implementando todo su tiempo en una lucha por el bienestar social; si esta actividad es lo que verdaderamente complace al individuo, entonces, inmediatamente deja de tener el calificativo de "sacrificio". Esto debe ser una cualidad fundamental en el Revolucionario, sentir la misma - revolución- como tal, para trabajar con esmero. Pero no todo es tan simple, como en todo existe también su lado oscuro, la parte más dura de ser un revolucionario es que se deben definir de manera precisa los sentimientos, ya que todo revolucionario debe estar impulsado por grandes cantidades de amor aunado a un gran espíritu apasionado; para así realizar un caudal de acciones y hechos concretos orientados hacia un solo objetivo: lograr mejoras en el ambiente social. Estas dos condiciones o cualidades para ser revolucionario deben estar respaldadas por un factor fundamental que 
tiene que estar presente en la actitud de dicho individuo, y viene siendo la vigencia de una mente fría y calculadora que ayudará, sin duda alguna, a tomar decisiones dolorosas que no permitan ni siquiera la contracción de un músculo. ${ }^{34}$

Y es que estamos hablando de un nuevo sistema económico, político y social que se fundó sobre la base del compromiso del pueblo con la construcción del socialismo. No se entendía como un sacrificio: poder apoyar las tareas de la Revolución era la obra más noble a realizar. Se trataba de un sentido del deber social, y aquí no podemos evitar pensar en el militar, esa idea de servir a la nación, de formarse para mantenerla salvaguardada. Es entonces cuando la última frase nos devuelve al inicio de nuestra reflexión: la necesidad de una mente fría y calculadora que les permita actuar como máquinas, tomar decisiones donde la humanidad no tiene mucha fuerza de acción.

Luego Canelón retoma cuál es el papel de la Guerrilla en la edificación de la nueva patria. En este sentido, debemos tener en cuenta que la Revolución cubana enarbola la heroicidad de los guerrilleros alzados en la Sierra Maestra para liberar al país de la dictadura de Fulgencio Batista. Desde el inicio la imagen de los uniformados en las montañas, de Fidel Castro, Camilo Cienfuegos, el propio Ernesto Guevara, entre otros, comenzaron a operar en el imaginario popular, aliviando el pesar de un pueblo que había sufrido mucho el contexto político precedente. La Revolución cubana dio a los cubanos la oportunidad de vivir el sueño anhelado de la igualdad de derechos; por ello era tarea de todos mantenerla en alto. Devino una cuestión de agradecimiento y hasta de compromiso al inicio; más tarde, los errores cometidos en la política cultural, principalmente, con la puesta en práctica radical de nociones como la del "hombre nuevo", acabaron por poner en crisis esa construcción colectiva de la nueva Cuba.

34 Fidel Canelón, El Hombre nuevo según Che Guevara, 3-4. 
Sostiene Guevara que la guerrilla se desarrolla inicialmente en dos planos, en el primero se encuentra a la masa (pueblo) en estado de quietud, es estática (por lo que posteriormente habría que movilizarla) y, en el segundo, se observa a la Guerrilla; fundamentalmente motor impulsor de la movilización y a su vez generador de conciencia Revolucionaria y de entusiasmo combativo. Pero en ambos existe una semejanza: que el factor clave es el individuo y, gracias a sus actitudes, se crearán las condiciones subjetivas necesarias para la victoria. $^{35}$

Queda enunciado entonces que incluso el pueblo civil es un tipo de GuerriIla, la estática, la cual se piensa como un motor, pero en términos sociales, cada cual comprometido con su responsabilidad profesional; ante tareas de choque de la Revolución, ha de estar dispuesta a dar el paso al frente. Luego la Guerrilla en sí, el superlativo de actitud revolucionaria, fuerza motriz de la movilización y promotora de una conciencia íntegra y de un entusiasmo combativo. El militar en Cuba tiene esa connotación de impulso, de enaltecimiento de valores morales, de conducta intachable, de dignificación absoluta. Vestir el uniforme verde olivo era un honor, el más grande, pues los dirigentes de la patria lo portaban igualmente con todos sus honores y cargos a la hora de enunciar sus discursos. Ser un militar en la Cuba de la segunda mitad del siglo xx era la forma más pura de construir ideales.

¿Cómo se inserta entonces la idea de la homosexualidad en un contexto de "hombres nuevos"? Abel Sierra lo argumenta de la siguiente manera:

[...] mientras se (re)construía la nación y se diseñaba una sociedad diferente, la homosexualidad se insertó en el debate nacional como un elemento recurrente y contrastante con el hombre nuevo, concepto esbozado por Ernesto Guevara en 1965 y que fue el soporte simbólico-discursivo para establecer la nueva ciudadanía revolucionaria. El hombre nuevo pasa a ser el referente cultural autóctono y el ideal

35 Canelón, El Hombre nuevo según Che Guevara, 4. 
imaginario de la masculinidad nacional en esta etapa de efervescencia y necesidades históricas aplazadas durante mucho tiempo. ${ }^{36}$

No podíamos esperar entonces que en un entorno de ideales de guerrilla, hombres nuevos heterosexuales y la masculinidad como bandera, fuera respetado el derecho de todo ser humano a la preferencia sexual que desee. Por el contrario, se vio como un peligro al ejemplo que recibían los infantes que crecían con la Revolución, a la imagen del país en el extranjero en eventos culturales, e incluso como un signo de debilidad para el glorioso sistema socialista que se edificaba.

Ya dentro de las dinámicas militares encontramos que en tan sólo dos páginas el Juramento Militar concentra la política ortodoxa y de antaño que rige hasta hoy el ingreso al Servicio Militar. En este sentido, podemos apreciar la "agencia" del lenguaje, que según Butler, implica que un acto discursivo cuente con consecuencias. ${ }^{37}$ Cada término contribuye a la definición de ese sujeto ritual encarnado por el soldado. A continuación, algunos fragmentos significativos:

Juro:

$[\ldots]$

c. Ser activo constructor de nuestra sociedad, ejemplo de actitud y abnegación ante cualquier tarea. Enfrentar todo lo que atente contra la ley, lesione los intereses colectivos y el orden social, y mantener una consecuente vigilancia revolucionaria.

d. Ser ejemplo y cuidar siempre el prestigio de las Fuerzas Armadas Revolucionarias en todos mis actos, tanto en la unidad militar como fuera de ella; ser respetuoso con la población civil y mantener una actitud solidaria con ella, ser modesto y cortés con los que me rodean, en particular con las mujeres, ancianos y niños. ${ }^{38}$

36 Sierra, Del otro lado del espejo, 200.

37 Butler, Lenguaje, poder e identidad, 24.

38 Manual de la preparación básica del soldado (marinero), 388. 
Hasta aquí podemos reconocer ciertos términos e ideas que habíamos analizado anteriormente en el texto de Butler. Por ejemplo, la noción de que cualquier comportamiento indebido puede atentar contra el orden social, contra la colectividad, quizá por lo "contagioso" que puede tornarse de cara a la "normalidad" deseada en la sociedad. Igualmente, pienso en la cuestión de la vigilancia revolucionaria como aquella instancia encargada de denunciar lo incorrecto, lo fuera del orden, lo "diferente", y acorde con los terribles errores de discriminación que tuvieron lugar en esa limpieza social de lo que era o no revolucionario, no puedo evitar considerar cuántos estándares y paradigmas debía cumplir ese soldado.

No sólo "la salida del clóset", como acto voluntario de declaración de la sexualidad, sino también la acusación desde una instancia política de ser "homosexual", como si ello entrañara una deformidad o una herejía, son procesos de performatividad (puesta en acción), en los cuales el lenguaje perlocucionario es entendido como ilocucionario. Es decir, son afirmaciones que no toman cuerpo en el momento en que se enuncian, pues declararlo no implica consumar un acto sexual gay frente a quien se lo declaramos. Sin embargo, son entendidas como tal, pues decirlo genera la paranoia colectiva; en la psiquis de los otros se forma una imagen pecaminosa que ya no consideran ejemplar. En esta cuerda, el ejemplo se vuelve negativo, pues se trata de la ruptura de un tabú, el cual se considera que posee una fuerza sobrenatural para conducir a la tentación. ${ }^{39}$ Se desea aquello que no se puede tener, por eso quien se atreva a irrumpir las normas se convierte en un paradigma de lo incorrecto, de ahí la "necesidad" de aleccionamientos y marginaciones de estas figuras de organizaciones políticas, militares, y hasta públicas como la universidad, ya que hasta ésta era sólo para los revolucionarios.

Por ello, resulta llamativo el hecho de que para cuidar el prestigio de la FAR sea indispensable el llevar a cabo "actos" correctos, lo que — de acuerdo a

39 Cfr. Butler, Lenguaje, poder e identidad. 
lo que veíamos anteriormente con Butler- sería todo aquello que no corrompa la idea inmaculada de lo militar, pues aunque sea acometido una única vez será entendido como conducta para siempre. Si has robado sólo una vez, serás un ladrón y quedarás a menudo en entredicho; si has mantenido relaciones íntimas una vez con alguien del mismo sexo o tan sólo lo has besado serás tildado de homosexual, y así sucesivamente. No hay cabida aquí para el humanismo, para la posibilidad humana de errar en términos delictivos, ni la inherente transformación que sufre nuestra identidad en el tiempo, etcétera. ¿Cuál es la necesidad imperante de conceptualizar todo? En este caso, obviamente es tener un reglamento por el cual juzgar aquello que difiere de la regla. No podemos pasar por alto el hecho de que el soldado es el prototipo social que legítimamente posee el permiso para usar la fuerza, para confrontar al resto de los civiles; por ello se le supone como alguien moralmente intachable, destacado en todos los rubros y con la integridad necesaria para juzgar y marginar a aquellos que no cumplan esos requisitos.

Asimismo, la idea de ser respetuoso con la sociedad en la que uno se desarrolla es algo capciosa, si tomamos en cuenta que muchos sujetos dentro de ese entramado social tildan de irrespetuosa la condición de homosexual, en tanto le genera fugas al ejemplo heteronormado transmitido en sus familias. Lo militar invita a una identidad que puede ser construida sobre el tabú de la homosexualidad, un tabú que se transmite a nivel del inconsciente, y finalmente genera que en lugar de desaparecer acabe por preservarse y asegurar su lugar en la memoria colectiva. "La prohibición preserva el deseo". 40

El libro de Butler es posterior en casi una década al periodo de Servicio Militar de Adonis Flores en Angola y se escribió unos años antes de que comenzara la serie Camuflajes en 2003, pero sus consideraciones no están lejanas en el tiempo como para desestimar muchas de las teorías psicoanalíticas que propone para entender la postura hegemónica del ejérci-

40 Butler, Lenguaje, poder e identidad, 194. 
to. De ahí que, salvando las distancias de tiempo y contexto, podamos acercarnos a uno de los tópicos más polémicos del universo militar, la homofobia.

El ámbito militar es un espacio reduccionista, poco inclusivo, donde tanto la disciplina como los "valores morales" y de afiliación política acaban normándolo todo; no bastan la voluntad y el arrojo para someterse a esa vida: también es necesario ser capaz de encajar en la camisa de fuerza camuflada que se construye culturalmente para el futuro soldado. Es así que éstos terminan envueltos en un abanico de reglas no escritas que intentan normarlos como sujetos, las cuales van desde etiquetas discriminatorias como la condición de migrante, criterios racistas o múltiples variantes de homofobia. Esta última es una manera de circunscribir lo homosexual a una idea patológica de imágenes obscenas; de ahí su rechazo por muchos, que lo consideran algo propiamente abyecto.

¿Qué hacer entonces frente a la doble moral que bordea a estas figuras de poder, a quienes norman y regulan?, ¿qué hacer cuando no dan el ejemplo "positivo" que tanto exigen y por el contrario, de manera velada, acaban trasgrediendo las leyes? Estas preguntas sólo nos conducen una vez más a la humanidad inherente a todos, tanto a los que conducen las estructuras de poder como a los soldados que acatan órdenes. No se trata de máquinas, de ahí que el maniqueísmo militar acabe volviéndose inoperante con cuantiosas fugas en su reglamento.

\section{Forma y contenido en Camuflajes}

En primer lugar, apreciamos en la fotografía elaborada por Adonis Flores un afán nulo de contextualización; se trata de acciones "para disipar el miedo", como él las nombra, ${ }^{41}$ que buscan llamar la atención sobre gestos puntuales, los cuales funcionan como metáforas que nos conducen inmediatamente a otras lecturas. Así pues, podemos hablar de universalidad en

41 Crespo, Entrevista a Adonis Flores, 7 de enero de 2020. 
la serie Camuflajes en cuanto a que la vestimenta militar es una constante, a la vez que un convencionalismo alrededor del mundo. Por lo general los fondos son neutros, para así llamar la atención sobre el sujeto fotografiado, el propio artista en este caso. Cuando existe un background, como en El arte de la primavera (2004), éste se entremezcla con el artista, dando lugar justamente al camuflaje que nombra la serie.

El título nos contextualiza rápidamente, trata de explicarnos la razón de la presencia de las flores en la composición, nos guía la mirada hacia lo que Flores quiere resaltar. De todas las estaciones, la primavera es sin dudas la más alegre desde el punto de vista visual, la más femenina, la dadora de vida y su expresión más evidente y colosal es el florecimiento, de ahí que realice un contraste marcado con los conceptos que definen la imagen del militar. Adonis Flores se encuentra de pie e inmóvil sobre un campo florido de margaritas; su posición es erguida, su rostro serio mira al frente como quien espera una orden. ¿Qué hace un soldado en medio de ese verdor y esplendor primaveral? En perspectiva, el campo se extiende y vemos que está desierto; ¿quién acompaña a ese soldado?, ¿por qué se encuentra solo en medio de ese soleado día, con esas margaritas que acabaron trepándose a su uniforme hasta inundarlo?

La flor en esta obra es un indicio de femineidad, de color en medio del maniqueísmo blanco-negro que bordea lo militar. Se trata de la contraposición de dos universos opuestos: la puesta en tensión de lo recio, hierático y firme en contraposición con lo efímero, aromático, colorido y transformable. Quizá se encuentra solo en medio de esa inmensidad porque el espacio de la "otredad" es un sitio de soledad, de aislamiento, de vergüenza y humillación, donde se intenta seguir aquello que todos esperan de uno pero, cual flores sobre el cuerpo, los verdaderos rasgos brotan a la luz y entonces no hay cómo esconderse. Hay entonces una imposibilidad de camuflarse, una ruptura en términos simbólicos, una eclosión del absurdo, en tanto que las flores delatan aquello que debiera permanecer oculto. 


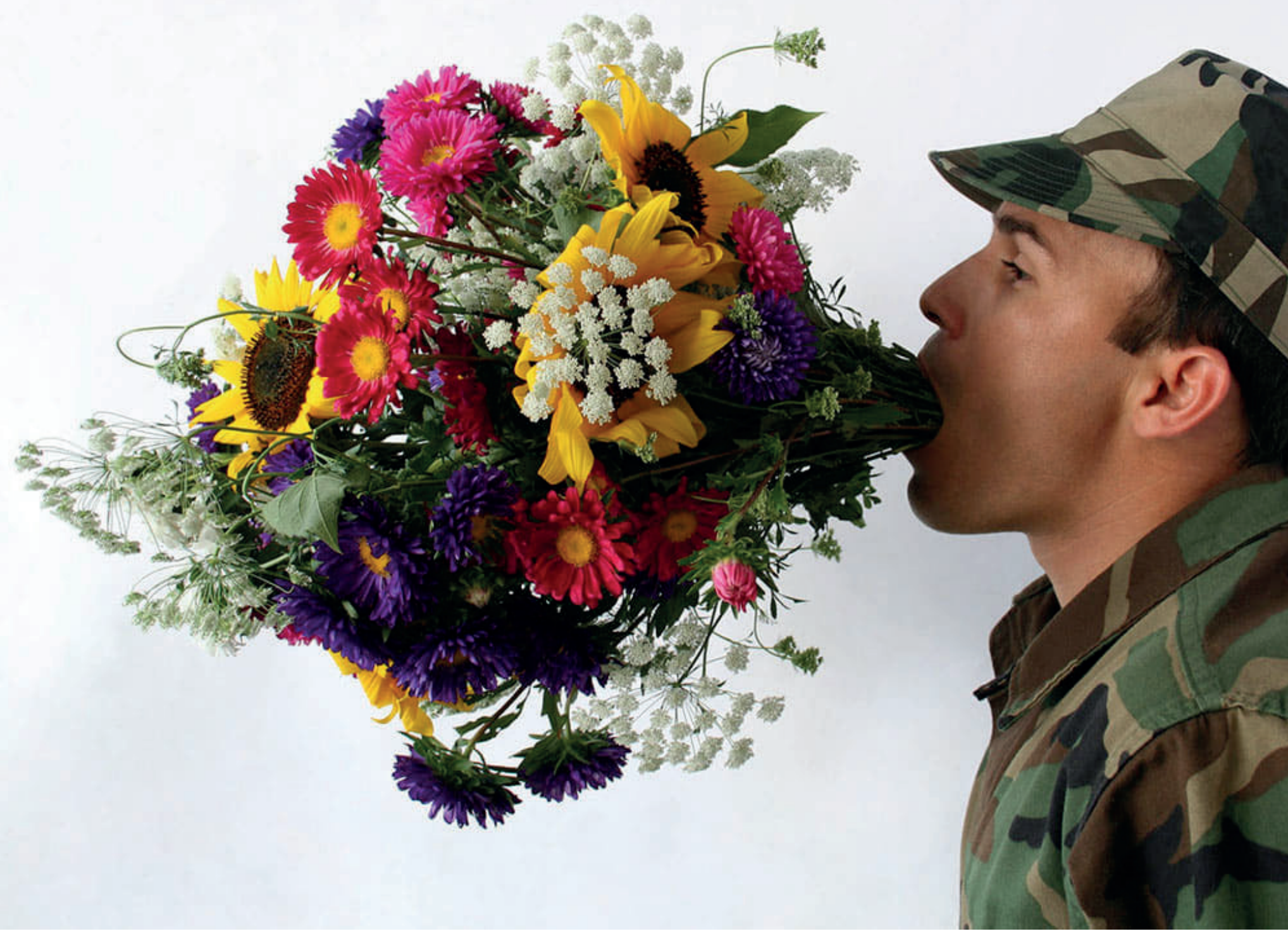

Figura 1. Adonis Mariano Flores Betancourt. Oratoria, 2007.

La utilización de las flores es una variante recurrente en esta serie; de ahí la presencia de obras como Oratoria (2007) y Honras fúnebres (2007), de las que se sirve para abrir el diálogo a cuestiones diferentes, pero igualmente generadoras de contrastes y oposiciones, con lo que se le crea un espacio al absurdo que radica en el control militar. En la primera, ante un fondo completamente neutro, el artista nos muestra su perfil izquierdo, mientras emana de su boca un ramo de flores. Una vez más con su uniforme y un título como Oratoria, el cual rápidamente remite a la locuacidad y convencimiento que debería reinar en el discurso militar; sin embargo, encontramos la violencia psicológica y la presión como prácticas más recurrentes. 
El artista vuelve sobre la dulzura que entrañan las flores; de hecho, no es un ramo de flores cualquiera, sino que es sumamente colorido, variado, diverso. El ramo es de flores artificiales y nos recuerda el contraste entre el arte como artificio y la naturaleza con su fuerza vital. A su vez, pudiéramos entenderlo como una naturaleza muerta, lo que ilustra la contraposición entre la vida que representa la naturaleza y el acecho de la muerte que acompaña la figura del soldado. El fotógrafo abre una vez más el espacio de posibilidad para lo variopinto y "diferente", sólo que esta vez lo más importante es caer sobre la fuerza de las palabras, lo que entraña el gesto de hablar, de discursar, de orar. ¿Qué cualidades debe poseer un buen orador? Es una manera de ser líder; de ahí la capacidad de movilizar a las masas, de llevarlas al convencimiento, de persuadirlas, de manejar la idea de la heroicidad como premio al sacrificio e incluso a la muerte. Vemos entonces que lo más importante en esa composición es el ramo de flores que "pronuncia" el artista, con todos los posibles matices que esto supone. Pero esta conclusión sólo es posible a través de la sugerencia semántica del título, que pone sobre aviso al receptor, impidiendo una tergiversación de la idea proyectada por el autor o condicionando aquello que él desea que veamos.

Por otra parte, aparece una obra como Honras fúnebres (2007), la cual trae a colación un tópico hipersensible al sujeto militar, pues en efecto vive en un constante juego o coqueteo con la muerte, así como con la capacidad (dada por la condición militar) de producir o dar muerte a otros. No sólo depende de esos otros si el soldado permanece un día más en el mundo, sino también pende de la conciencia del soldado que otros regresen a casa con vida. De ahí la referencia del hula hula, pues a diario se danza con la parca y es fruto del azar si se caerá el aro o no, más allá de las técnicas posibles e insospechadas que uno sea capaz de desarrollar en un afán de subsistencia o mérito ganador (en el caso del juego y también de la guerra). Esta imagen pertenece a la documentación fotográfica del performance homónimo, donde el artista baila el hula hula y el sonido extradiegético que acompaña la acción es una música fúnebre. El aro no se encuentra desnudo, sino que ha devenido en una corona de flores, mientras que el fondo una vez más neutro simula cierta aridez provocada por el propio tono ocre 


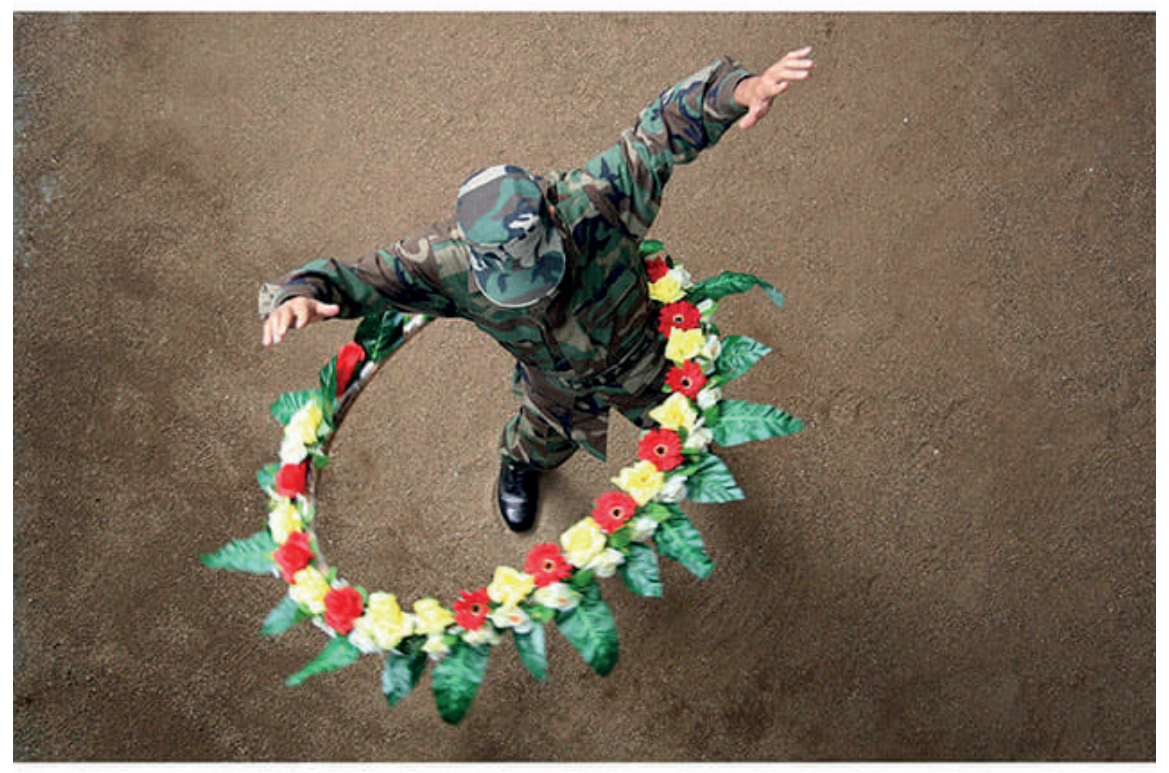

Figura 2. Adonis Mariano Flores Betancourt, Honras fúnebres, 2007.

que posee. ¿Acaso ante tanta presión y deber por cumplir se deja de sentir la presencia constante de la muerte?, ¿puede la muerte ser algo lúdico?, ¿pueden depender de un juego miles de vida humanas?, ¿los traumas de esta dolorosa experiencia sólo marcan al soldado, o la muerte también ronda las mentes y los corazones nerviosos de sus seres queridos? La guerra es un suceso que trasciende las subjetividades de cada implicado directamente para clavarse en la memoria colectiva de un país, de una cultura, pues se fracturan demasiados vínculos y acaban generándose vacíos insustituibles.

Al fotógrafo le inquieta el espacio de exclusión que se genera en el interior de lo militar, ya que todo lo entendido como fuera del marco heteronormativo está condenado al acoso psicológico y hasta físico. Asimismo, el adoctrinamiento militar se ha caracterizado por la enseñanza basada en la exigencia extrema, conquistando en ocasiones zonas de violencia simbólica. Para acercarse a este tópico el artista se concentra en un detalle: sólo un close-up dentro de la postura de "en su lugar: jdescansen!". Que sea un detalle resalta la 


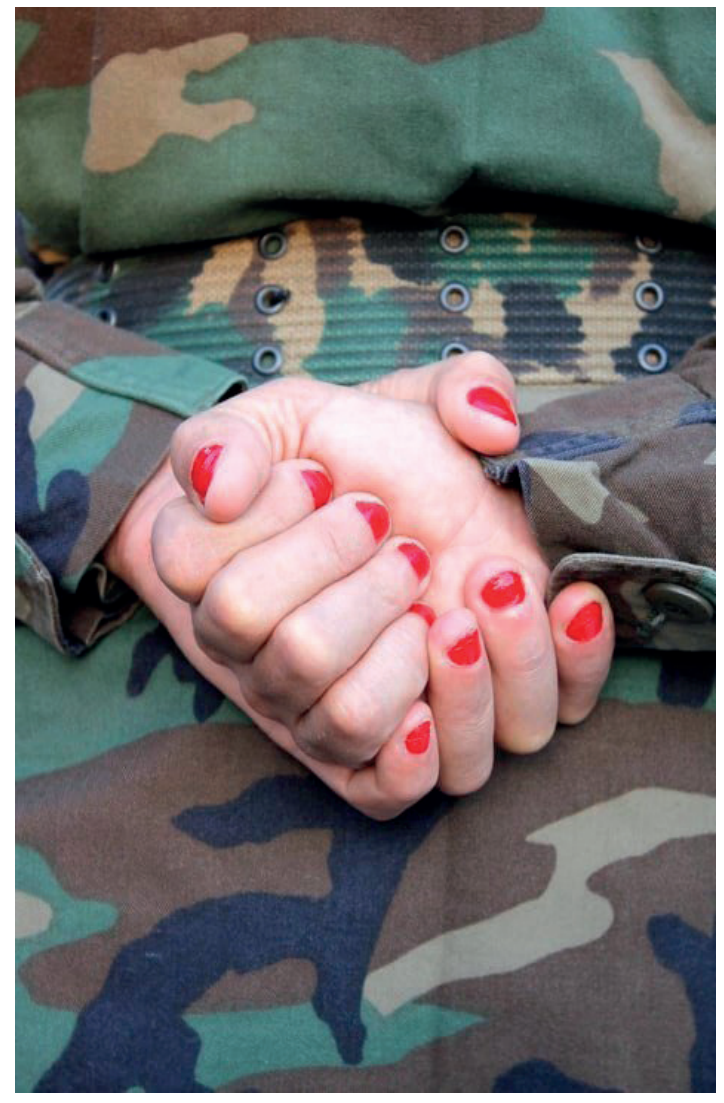

Figura 3. Adonis Mariano Flores Betancourt, Descansen, 2008. monumentalidad de los elementos visibles: una vez más el uniforme, las manos en la manera que lleva la posición militar, y el sutil y llamativo dato de que las uñas del soldado están pintadas de rojo y sumamente carcomidas. Son manos que se encuentran escondidas, lo que vislumbra un doble camuflaje, o una suerte de ocultamiento. Manos que no se muestran, ¿por qué? Obviamente hay algo que debe permanecer en las penumbras, en silencio. Las uñas pintadas lo gritan a cuatro voces, el deseo de presumir, de ataviarse, de pintarse y sentirse femenino se oculta tras ese soldado, las uñas carcomidas evidencian estados de nervios donde la ansiedad domina la situación. Es entonces cuando se nos revela el título de la obra, un elemento altamente clave en toda la serie:

Descansen (2008), y ésa es la verdadera pregunta: ¿descansar de qué? Pues hace falta cada cierto tiempo un respiro, un espacio para relajarnos y poder ser completamente nosotros. Esta obra podría problematizar sobre eso, respecto a una pretensión constante en aras de encajar en un entramado social, mientras guardas u ocultas "otras manos", las verdaderas, las que provocan felicidad y aplauden la bella rareza de nuestras individualidades.

El contraste cromático es muy fuerte, dada la combinación de colores complementarios como el verde en sus diversas variantes y el rojo de las uñas. Cada elemento está dispuesto en función de un plano: el uniforme nos remite directo a Adonis Flores, quien para el momento de realización de esa obra ya llevaba cerca de cinco años trabajando con la estética del camuflaje militar; la posición de las manos expresa una obediencia que espera poder diluirse ante esa postura de descanso, de descompresión. Esta pieza habla de la presunta debilidad que se esconde tras el prototipo de militar 


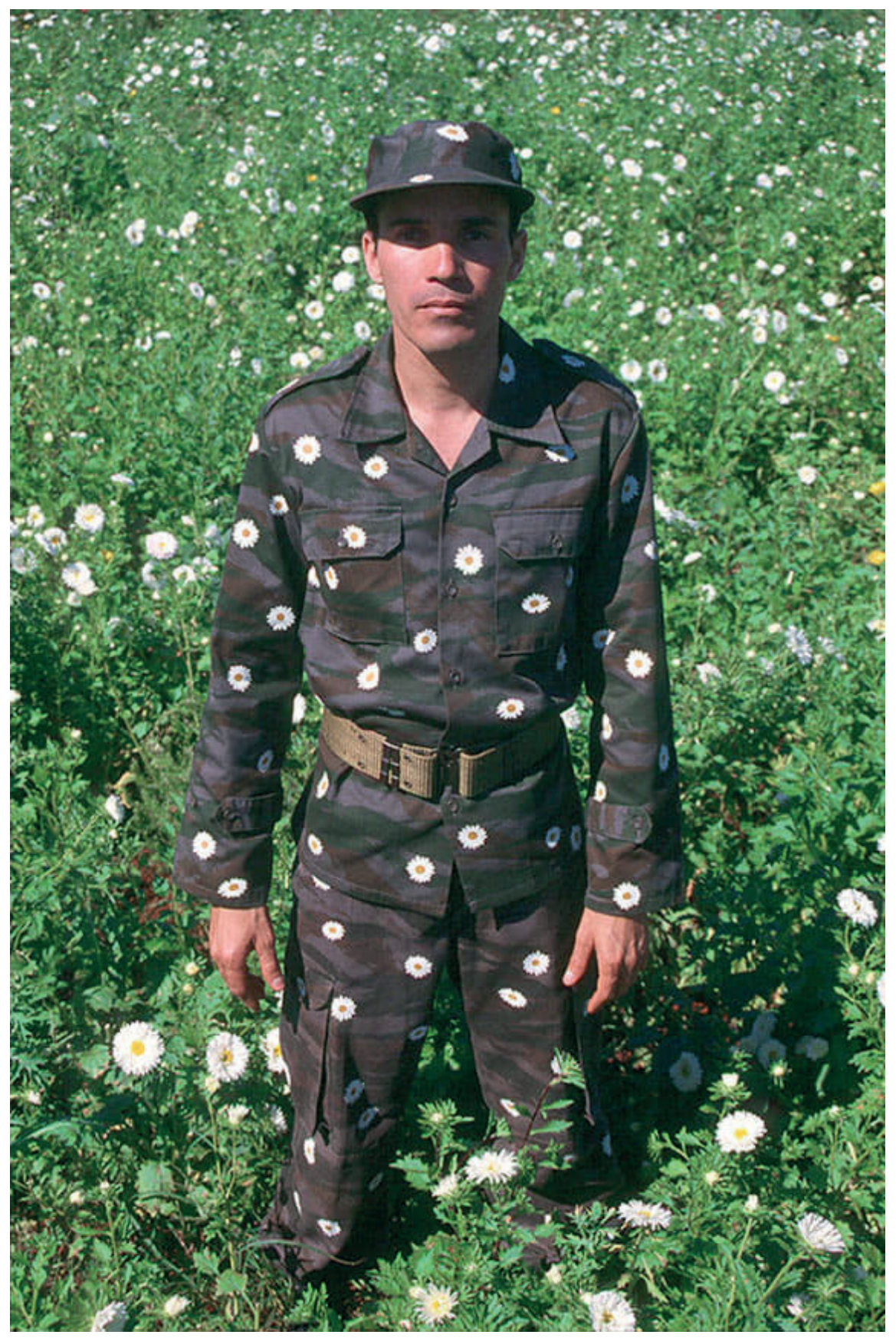

Figura 4. Adonis Mariano Flores Betancourt, El arte de la primavera, 2004. 
que se debe cumplir: ¿acaso resulta posible ese stop dentro de las normas sociales que dictan "el deber ser" de un soldado?

Las obras anteriores evidencian un uso exquisito de la metáfora como figura retórica del discurso artístico, a partir del uso de elementos que contribuyen a dotar de un nuevo sentido la visualidad naturalizada. Existe un desplazamiento semántico constante entre elementos diferentes: ramo de flores = discurso militar y el hula hula = corona funeraria como ejemplos más claros. Sin embargo, la mayor metáfora aquí sería el soldado, quien es puesto en situaciones propias de la cotidianidad de cualquier sujeto corriente, cuestión que causa un quiebre en el entendimiento de la obra y de la que emana su lectura reflexiva. Este proceder:

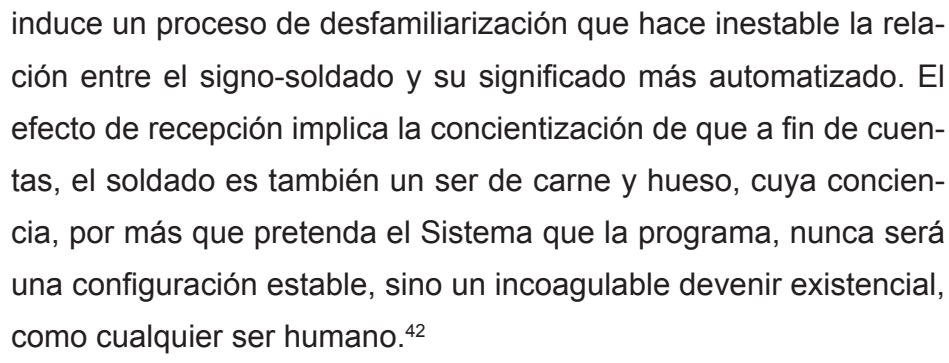

Como parte del proceso artístico de la construcción de la imagen, podría surgir la interrogante de si el artista es el portador de la idea y, a la vez, el modelo. ¿Quién toma la foto? En su caso no es la propia cámara programada, sino la artista visual Marianela Orozco, igualmente especialista en términos fotográficos, con quien él acaba haciendo una suerte de equipo de trabajo. En ocasiones él la asiste a ella de igual forma y a partir de la empatía y el fluido intercambio de ideas, la artista ejecuta aquello que Adonis Flores tiene en su mente y quiere lograr con la lente. Otras veces, para obras más complejas, ha requerido de otros fotógrafos aparte de Marianela Orozco; de ahí que se convierta, más que en fotógrafo, en director de fotografía. Dirige mientras actúa, tiene la palabra final sobre cómo debe que-

42 Fernández, "Camuflajes, metáforas y metonimias", 14. 
dar la foto, porque en función de su engrane con la idea a priori, estará la fuerza comunicativa que logre sobre los espectadores. Hay premeditación: se trata de una fotografía que se construye, en la que cada elemento o postura desempeña un papel específico. En la pieza Aliento (2006) encontramos un ejemplo de ese trabajo en equipo de estos dos fotógrafos como complemento para la concepción de la obra.

En esta fotografía, el autor se encuentra en posición yacente, y de su boca sale un abultado grupo de plantas silvestres, de las que crecen en todas partes de manera espontánea y que luchamos por mantener ausentes en los jardines. Popularmente llamada "maleza", es lo que crece encima de cualquier cosa, que opaca el esplendor de otras plantas más hermosas y que resurge una y otra vez hasta en la tierra más árida. Nos remite entonces a la idea de que una vez muerto, el soldado desaparece en el campo de batalla, y pasa a formar parte de la tierra. Una alusión quizás al propio acto de enterramiento, donde igualmente acabamos en el subsuelo. El uniforme como una constante que nos remite al rol del soldado, sus ojos cerrados refuerzan la idea de la muerte, del yacimiento, de la desaparición del mundo de los vivos. También puede hacernos pensar en los tiempos muertos dentro de los conflictos bélicos, en los que esperan camuflados entre el pasto el momento de proseguir.

Asimismo, vemos que la fotografía no siempre es un medio en sí mismo, aun cuando por su cualidad expedita resulta muchas veces más viable. Más bien, la fotografía es el soporte de la interdisciplinariedad que caracteriza a Adonis Flores. Le funciona para documentar performances, bocetar esculturas, proyectar instalaciones, atrapar los momentos climáticos de las videoinstalaciones, dibujar algo que posee referente figurativo, etcétera.

En esta línea, la serie cuenta con otro grupo de obras que se basan en sátiras a la rigidez y heteronormatividad del ámbito militar, por ejemplo Visionario (2003). Ésta es una de las primeras obras de Camuflajes, con una relativa proximidad en datación a la caída de las Torres Gemelas, con el consiguiente razonamiento del artista respecto a la situación de vulnerabi- 
Nierika 20 - Año 10 - julio-diciembre de 2021

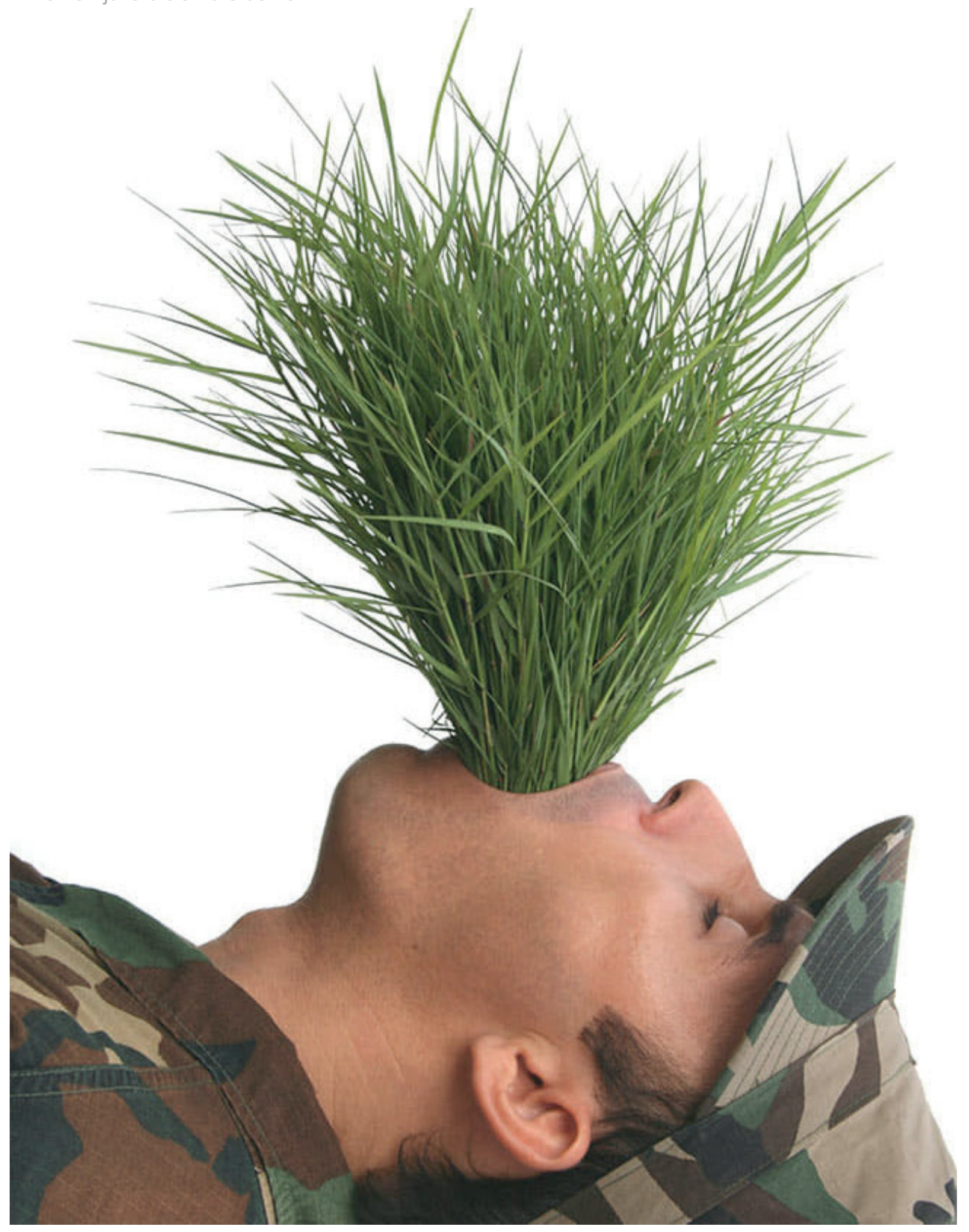

Figura 5. Adonis Mariano Flores Betancourt, Aliento, 2006. 


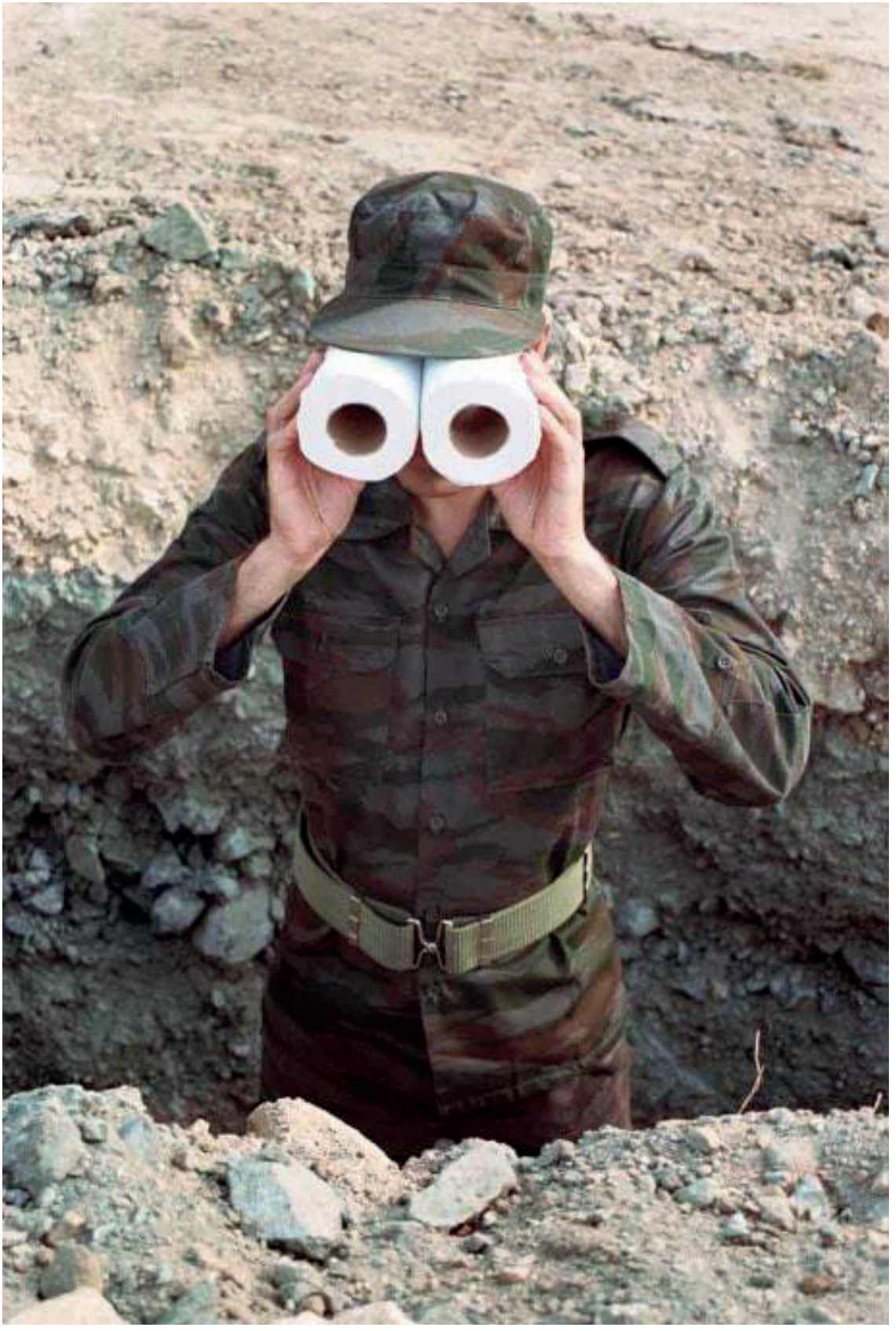

Figura 6. Adonis Mariano Flores Betancourt, Visionario, 2003. 
lidad que invadió el mundo entonces. Es así que hallamos al artista sumergido en un espacio intermedio entre dos formaciones rocosas, áridas una vez más, como quien se oculta para expiar las acciones del enemigo; una especie de trinchera que en esas dimensiones remite al absurdo, pues realmente no cumple su función. Uniformado y de pie, sostiene unos binoculares, observa algo que no vemos por el ángulo desde el que fue tomada la fotografía; pudiera incluso mirarnos a nosotros. Sin embargo, los binoculares están constituidos por dos rollos de papel sanitario, y no podemos ver el rostro del individuo pues desaparece tras este original artefacto. ¿Qué puede observar realmente? No hay aumento en el "vidrio" a través del que mira, no hay tecnología que le permita escudriñar algo a larga distancia, no hay visión alguna (como dicta el título de la pieza).

Lo único que encontramos entonces es la fragilidad del gesto de mirar (que sugiere lo endeble del material de estos binoculares sui generis), de acertar en las decisiones de aquello que vemos (o imaginamos) que se nos viene encima. Se dialoga en torno a la susceptibilidad de todos los implicados en estos sucesos bélicos, de lo desechable de la vida, de lo prescindibles que acabamos siendo, de nuestro estar finito en el mundo. Es una pieza contradictoria, hecha como una de las primeras acciones del artista para "disipar el miedo", ${ }^{43}$ pero que acaba acrecentándolo en gran medida. Lejos de hallar un vigilante que vela por todos, que nos protege, muchos verán un sujeto igualmente vulnerable, expuesto y necesitado de protección.

Por otra parte, resulta necesario apuntar que la pieza devino luego performance con varias ediciones: dos de ellas en ciudades canadienses (Toronto y Kitchener) y otra en Inglaterra (Nottingham). Allí, el artista caminó por las calles, deteniéndose a observar con sus binoculares sobre todo lugares institucionales de importancia, sedes gubernamentales y demás, como una suerte de vigía en la búsqueda de algo sospechoso. Es un gesto que pone sobre la mesa la paranoia contemporánea, el escudriñamiento constante ante la sensación de estar en peligro o de ser observados. A la vez,

43 Crespo, Entrevista a Adonis Flores. 
que los binoculares estén constituidos por papel sanitario saca al debate el tema de la higienización social, la necesidad de desaparecer aquello que estorba, que apesta, que necesita ser borrado del mapa dada su inconveniencia para el sistema. De ahí que el acto de observación y vigilancia entrañe un gesto de limpieza social y política. Los manicomios y las cárceles son centros donde esconder esos "desechos", esas "impurezas", y el soldado es un medio para esos fines. Es su deber primero detectar la pestilencia y luego desaparecerla.

Una vez más, repito la importancia medular de los títulos en la lectura de las obras, pues nos ayudan a centrarnos en los tópicos sobre los

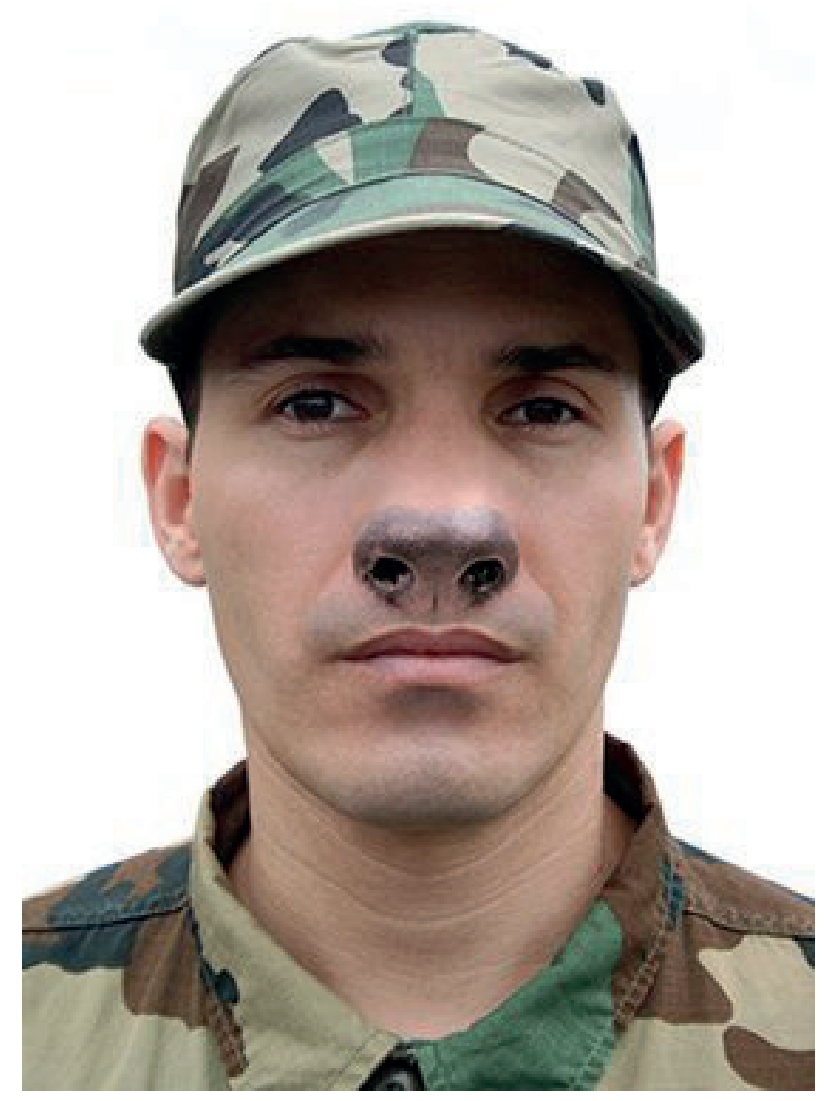

Figura 7. Adonis Mariano Flores Betancourt, Cazador, 2006. que el artista quiere llamar la atención. Por ejemplo, en Cazador (2006) inmediatamente nos remitimos al instinto animal del hombre, ése que en situaciones de catástrofes y enfrentamientos bélicos debe salir a la luz si se quiere permanecer con vida. Adonis posee una nariz de perro, símbolo del olfato que rastrea a la presa hasta encontrarla. El sentido del olfato es puesto en su estado más primitivo, como depredador que sigue el rastro de su víctima hasta devorarla. Las guerras desatan ese salvajismo y barbarie hasta llevarlos a su paroxismo. Ahora bien, resulta interesante cómo en estas situaciones extremas de violencia física y psicológica se vale absolutamente todo, cada acción que en un entramado social normal se consideraría barbárica y enfermiza, en el campo de batalla toma razón de ser. Es como si generaran soldados máquinas, capaces de ser programados para la civilidad de la vida cotidiana y luego para los desmanes de la guerra. 


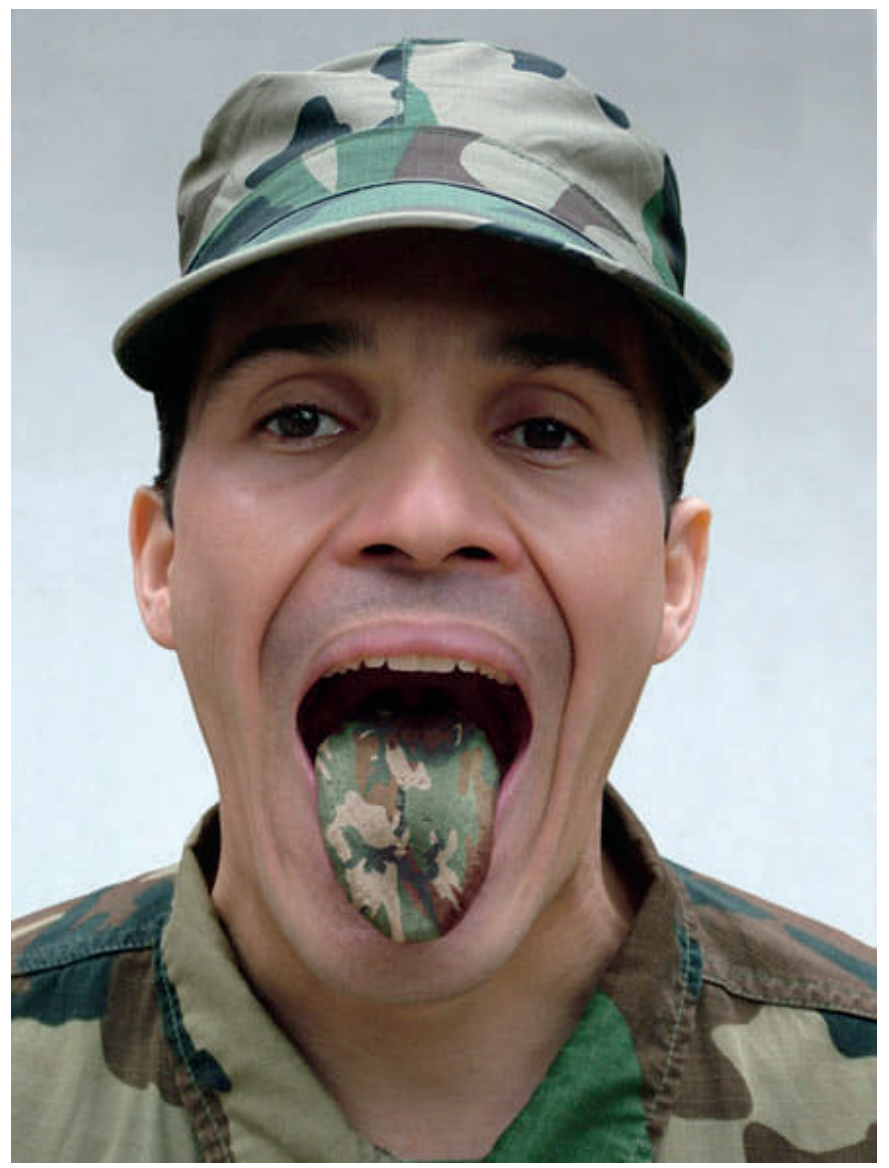

Figura 8. Adonis Mariano Flores Betancourt, Lenguaje, 2005.
Igualmente, en Lenguaje (2005) se vuelve sobre la idea de las mentes programadas por el sistema militar, una suerte de lavado de cerebros donde todo se vuelve congruente para el soldado y el cumplimiento de órdenes deviene su razón de ser. Este fenómeno el artista lo representa con la propagación del camuflaje hasta la lengua del sujeto. Ya no sólo lo porta como símbolo de pertenencia, sino que todo lo que salga de su boca acabará legitimando este poderío militar, esa fuerza imparable. En este sentido, se explicita "la idea de que los intereses del Sistema han terminado por colonizar la psiquis del sujeto, en tanto el lenguaje, como estructura de pensamiento, ya sólo habla mediante los códigos del camuflaje". ${ }^{44}$ Esta idea ya la veíamos anteriormente en el poder de agencia del lenguaje, en las consecuencias a posteriori que genera, en la performatividad de actos que se deslindan de éste. El lenguaje tiene una fuerza que se traduce en actos; es el principio de conductas y hasta de imaginarios. Todo parte de él en alguna medida.

Asimismo, encontramos el caso de Mascarada (2006), donde una vez más el camuflaje se ha expandido a otras zonas del cuerpo, en este caso el rostro. Sin embargo, no es un camuflaje ordinario, común, más bien se trata del maquillaje propio de un payaso a partir de los tonos que conforman el uniforme militar. ¿Qué quiere decirnos el artista? Quizá llama la atención sobre la bufonería del entorno militar, la cual se expresaría en dos posibles senti-

44 Fernández, "Camuflajes, metáforas y metonimias", 14. 
dos: el primero, en el rol de los dirigentes que muchas veces sin la capacitación necesaria se sienten con el derecho de avasallarte y pisarte la cabeza con su robusta bota, y el segundo, en la figura del desvalido soldado, sometido a todo lo que le ordenen como sujeto liminal que es, presto a convertirse en un hazmerreír de todos, en el objeto de burla, hasta llegar a la contradicción emocional del payaso, el tener que hacer reír cuando puede ser que desee llorar. De hecho, la expresión de su rostro sugiere más el llanto propio de la tristeza que la risa provocada por la alegría.

La fotografía Carne de cañón (2007) le dio nombre a la exposición del artista en Galería Habana, Cuba, cuando expusiera por primera vez la serie, como enun-

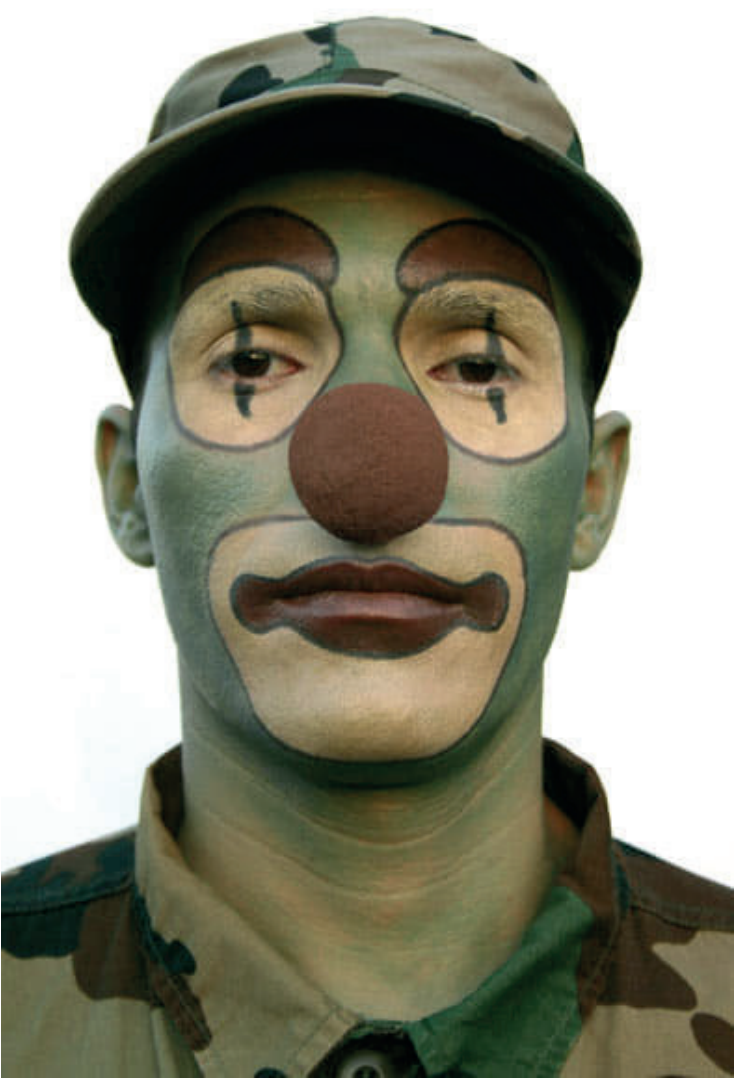
ciaba anteriormente. Se trata de una obra algo grotesca que llama la atención sobre un tópico inherente al orden militar: el anonimato de aquellos que dan la vida en el campo de batalla. El propio título lo enuncia, son conejillos de Indias, vidas que no importan y por eso pueden ser sacrificadas. De hecho, al referirnos a la expresión "carne de cañón" pensamos en personas que por su baja condición social pueden ser expuestas a cualquier peligro o daño, de ahí que sea una realidad triste encarar la cuestión de entender a todos estos soldados como tal.

Una vez más yace sobre el suelo, mediante el uso de carne cruda ha logrado simular el rostro de un soldado que ha sufrido las consecuencias de una explosión. Tiene el rostro desfigurado, calcinado, deshecho. Se trata de un cuerpo desvencijado, que pierde su identidad, su valor como repositorio de 


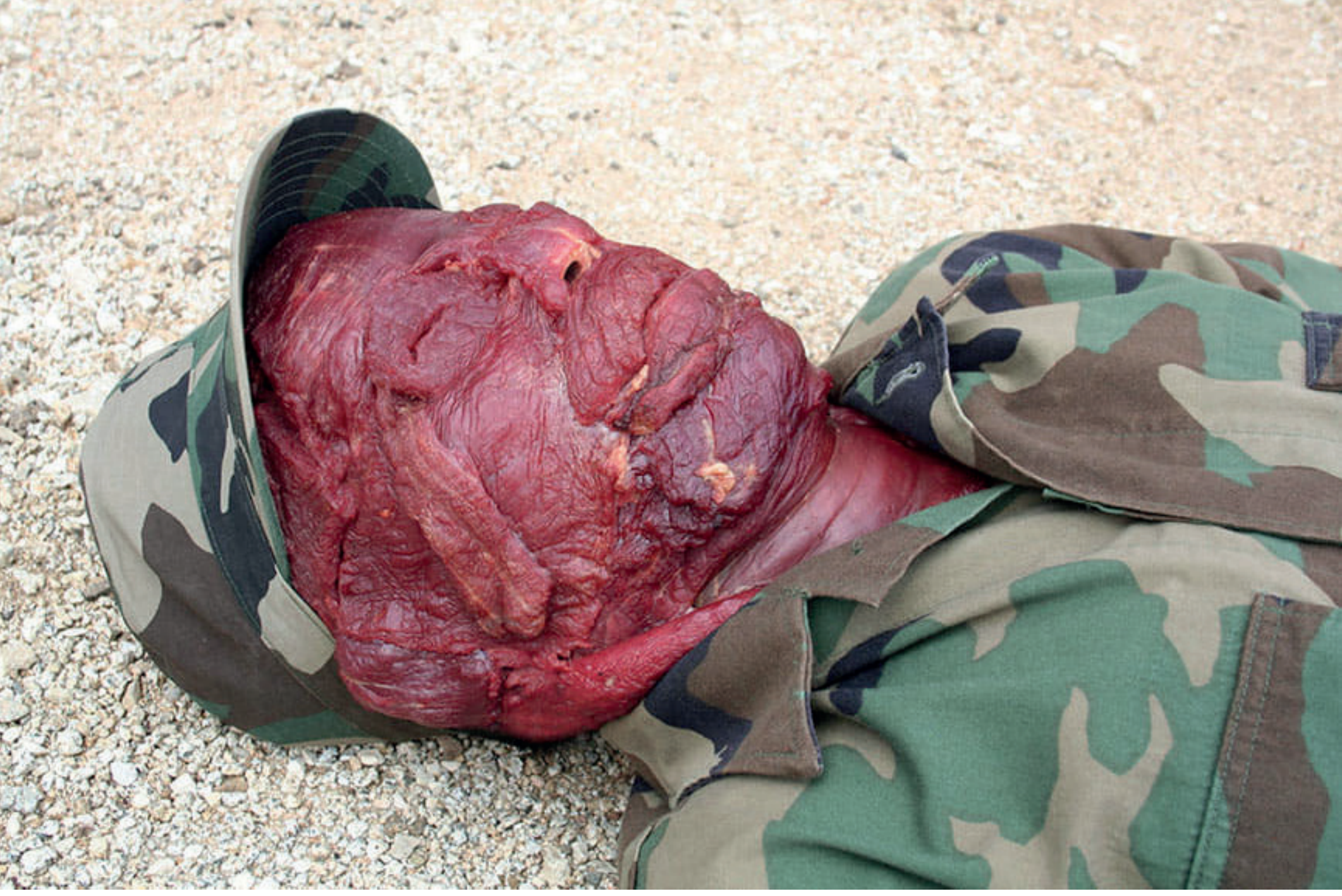

Figura 10. Adonis Mariano Flores Betancourt, Carne de cañón, 2007.

identidades. El cuerpo está tan destrozado que no se puede reconocer, amén de las chapillas identificatorias que como marcas de ganado permiten asociar cuerpos con identidades, pero ¿dónde están los rasgos físicos que marcan nuestra individualidad?, ¿qué sucede en esa imposibilidad de identificación?

Es el tipo de cadáver que al volver al hogar no podrá ni ser velado; es cualquier cosa menos ese hijo, padre o esposo que despedimos al marchar a un conflicto bélico " $x$ ". Se trata de uno de los mayores traumas que cargan las familias de estos sujetos-rol: ya sea su regreso como algo distinto, como muestra esta imagen, o su no regreso, tras haber explotado en el aire o no haber podido ser recuperado el cadáver. No creo fortuito entonces que esta obra le dé título a la exposición. Ella representa el sumun de la crítica al establishment que el artista inicia desde Visionario o El arte de 
la primavera. Deja a un lado la metáfora y la estetización del mundo bélico, en aras de hacer totalmente explícito el dilema y su denuncia del mismo. Esta pieza proclama el cuerpo como despojo, como algo que no tiene valor, y por ende carece de decoro, pues no está en condiciones de ser exhibido en un funeral militar con su uniforme glorioso, sinónimo del heroico cumplimiento del deber.

La participación de Adonis Flores en la guerra de Angola con apenas 18 años de edad, como parte del cumplimiento del Servicio Militar, nos lleva al análisis del papel de la juventud en la Revolución cubana, considerada como la esperanza de futuro para el país, y en el caso de la organización política (UJC), la cantera del Partido Comunista de Cuba. Con el triunfo de la Revolución, la defensa del país dejó de ser tarea exclusiva del órgano armado para devenir misión de todo el pueblo.

Ernesto Guevara en su conceptualización del "hombre nuevo" expresaba el papel fundamental de la juventud en el proceso de construcción del socialismo:

[...] por ser una especie de arcilla maleable con la que se puede construir al hombre nuevo sin ninguna de las taras anteriores. Ella recibe un trato acorde con nuestras ambiciones. Su educación es cada vez más completa y no olvidamos su integración al trabajo desde los primeros instantes. [...] el trabajo es un premio en ciertos casos, un instrumento de educación, en otros, jamás un castigo. Una nueva generación nace..$^{45}$

Es así que los jóvenes fueron potenciales en todas las tareas de paso al frente, desde las brigadas de alfabetización hasta la guerra internacionalista. La corta edad con que ingresaban al servicio militar realmente no los dotaba de la madurez para evaluar las connotaciones de esa decisión de coraje y valentía; en efecto eran tan dúctiles que se les podía convencer fácilmente bajo las promesas del heroísmo y la gloria. Ser soldado no fue

45 Ernesto Guevara, El hombre nuevo, 20. 
un trabajo más, fue la manera más digna de enarbolar ideales, de servir a las políticas solidarias del país, y un mecanismo para "forjar el carácter" de estos jóvenes. Esa nueva generación fue a varias guerras, cumplió con honor numerosas misiones de la patria; muchos no volvieron, otros lo hicieron con traumas insuperables y cuantiosas familias penan hasta hoy sus ausencias en cuerpo o alma. La carne de cañón parece no merecer otra oportunidad, el fundar una familia o realizarse profesionalmente, es una vida robada desde la hora en punto en que son elegidos.

\section{Colofón}

La serie Camuflajes de Adonis Flores puede ser dividida en dos momentos, de acuerdo con la intencionalidad de las obras y el tipo de visualidad que acaba construyendo: uno, dedicado a la deconstrucción del imaginario rígido y heteronormado del militar; otro, enfocado en la sátira de ese "prototipo social", imagen que carga ya con lecturas desde la política y que descansan en la particularidad del contexto cubano. De ahí que podamos hablar de un primer grupo de obras que se construyen mediante el contraste entre la femineidad otorgada a determinados elementos o procederes y la ortodoxia que acompaña el entorno militar y, en un segundo grupo aquellas que ponen sobre la mesa cuestiones como la existencia de un discurso vacío, la bufonería que entraña cierta doble moral en los que dirigen, las porosidades que inundan la rectitud que "definen" a los individuos, etcétera.

A diferencia de las obras fotoperiodísticas sobre el tema bélico, consideradas altamente históricas, la fotografía que Adonis Flores nos propone en esta serie funciona igualmente como documento, pero, en este caso, una crónica ya intelectualizada del fenómeno histórico. Sin afanes de reconstruir el tiempo cronológico, o de legitimar una verdad absoluta y confiable sobre los hechos, es una página de reflexividad para repensarnos el universo militar con ojos más flexibles, acordes con los tiempos que corren. 
El cuerpo es en esta serie de Flores el vehículo para contar la experiencia, la manera de reconstruir un testimonio, el lenguaje como agencia que posee connotaciones que lo trascienden y la identidad de ese sujeto que es generado por el sistema, como si fuera una máquina. Cada obra está pensada y elaborada a partir del cuerpo del soldado que busca reivindicarse; el artista es un medio para ese discurso de muchos con historias similares, y decide ser el portavoz visual de todas las problemáticas abordadas anteriormente. Es por ello que Adonis Flores deconstruye conceptos que tanto él como otros naturalizaron en su momento. En este afán, los títulos de las piezas completan esa intención autoral, al servir de vector que indica hacia dónde debemos mirar, dónde está el acento en la idea que nos propone el artista. Igual e inevitablemente, eso termina por condicionar la recepción de la obra, en función de ver primero donde el artista nos muestra, y en un segundo momento continuar nuestro vuelo imaginativo en la lectura de la pieza.

Camuflajes es una serie de inicio pero a la vez de transición, pues llevó al artista a otra etapa en su poética, en la que desaparece el sujeto-soldado y sólo queda la indumentaria militar. Hay un paso de la metáfora a la metonimia y fungen como ejemplo de ello obras como Crisálida (2008) y Lima (2009), de la exposición Memorial (Galería Habana, Cuba, 2010). Ya no está Adonis Flores, desaparece el cuerpo, ha llevado su quehacer a una expresión minimal, a una síntesis de su discurso donde el cuerpo del soldado sólo aparece a partir de su evocación simbólica, como quien porta toda esa parafernalia militar. En tanto, en Camuflajes se encuentra el afán constante de trabajo con el cuerpo de ese soldado (tipo social) que él representa. Tanto en las imágenes fotográficas como en los performances de la serie, su mayor objetivo parece ser quebrar la disciplina, el orden y la racionalidad del entorno militar, siendo ése el rasgo más característico que aúna las obras analizadas a otras bajo un mismo criterio curatorial.

En este grupo de fotografías se pone de manifiesto un conflicto perenne entre la persona (ser humano de carne y hueso con una conciencia que lo llama a contar todo el tiempo) y el militar (una máquina creada por la institución represiva que es el ejército). De esa tensión surgen entonces los 
traumas psicológicos y el desequilibrio que entraña esa experiencia dolorosa. Muchos filtros se rompen, un sinfín de sentimientos se quiebran y las emociones se descontrolan. Adonis Flores devela en esta serie la retorcida manipulación que subyace en el orden militar, la cual lleva a miles de hombres a matar a sus semejantes, en un afán de exterminio masivo, con el lema "mata o muere" como la almohada donde duermen. Lo más frustrante es el hecho de comprender que "lo militar" sigue actuando hasta hoy como parte de una costra histórica que lo ampara y que sigue dejando a su paso miles de víctimas. En palabras del historiador del arte cubano Hamlet Fernández: "en Camuflajes el planteo metafórico se vuelve por excelencia una acción de deconstrucción, que pone en crisis con cada obra la relación entre el sujeto-rol y la autoconciencia programada para este por el Sistema". ${ }^{4}$

\section{Bibliografía}

Antón, Héctor. "Adonis Flores: El maquillaje de la crueldad". Incubadora Ediciones. Disponible en https://incubadorista.files.wordpress.com/2020/02/ el-maquillaje-de-la-crueldad.pdf.

Butler, Judith. Lenguaje, poder e identidad. Madrid: Editorial Síntesis, 1997. Canelón, Fidel. El Hombre nuevo según Ché Guevara. Caracas: Universidad Central de Venezuela, Cátedra Historia del Pensamiento Político, s/a.

Cano, Alexander. "De la historia de las mentalidades a la historia de los imaginarios sociales". Ciencias Sociales y Educación, 1, núm. 1 (2012).

Castro, Elvia Rosa. "Adonis Flores. La paranoia como culto al vacío", Sr. Corchea, 2019. Disponible en https://elsrcorchea.com/2019/08/11/adonis-flores-la-paranoia-como-culto-al-vacio/.

Castro, Fidel. Discurso pronunciado por el Comandante en Jefe en la clausura del Acto para conmemorar el VI aniversario del Asalto al Palacio Presidencial. Universidad de la Habana, 13 de marzo de 1963. Disponible en http://www.fidelcastro.cu/es/discursos/en-la-clausura-del-acto-para-conmemorar-el-vianiversario-del-asalto-al-palacio.

Congreso Nacional de Educación y Cultura. Memorias. La Habana: MINED, 1971.

46 Fernández, "Camuflajes, metáforas y metonimias", 14. 
Fernández, Hamlet. "Camuflajes, metáforas y metonimias”. En Adonis Flores (libro catálogo). La Habana: Galería Habana, 2014.

Galán, Genevieve. "Aproximaciones a la historia del cuerpo como objeto de estudio de la disciplina histórica”. Historia y Grafía, núm. 33 (2009).

Guevara, Ernesto. El hombre nuevo. unAm-Coordinación de Humanidades, Centro de Estudios Latinoamericanos, Facultad de Filosofía y Letras / Unión de Universidades de América Latina, 1978.

Manual de la preparación básica del soldado (marinero). La Habana: Centro de Información para la Defensa, 2008.

Sierra, Abel. Del otro lado del espejo. La sexualidad en la construcción de la nación cubana. La Habana: Fondo Editorial Casa de las Américas, 2006.

Van Gennep, Arnold. Los ritos de paso. Madrid: Taurus, 1986.

\section{Entrevista}

Crespo, Dayma. Entrevista a Adonis Flores. La Habana, 7 de enero de 2020.

\section{Dayma Crespo Zaporta}

Licenciada en Historia del Arte por la Universidad de La Habana, 2017. Estudiante de la Maestría en Estudios de Arte de la Universidad Iberoamericana Ciudad de México. Ha sido docente de Antropología y Estética en la Universidad de las Artes (ISA) en Cuba. Cuenta con un diplomado en Antropología del Instituto Cubano de Antropología (ICAN). Es crítica y curadora en eventos nacionales como la Bienal de la Habana y en exposiciones internacionales, además de editora y correctora de estilo de revistas cubanas como La Jiribilla, Movimiento y Upsalón. Sus intereses investigativos se centran en el estudio del cuerpo como vehículo para la construcción de una poética en el arte contemporáneo. Ha participado en eventos académicos nacionales e internacionales. Igualmente, tiene en su haber varias publicaciones en revistas cubanas indexadas. 